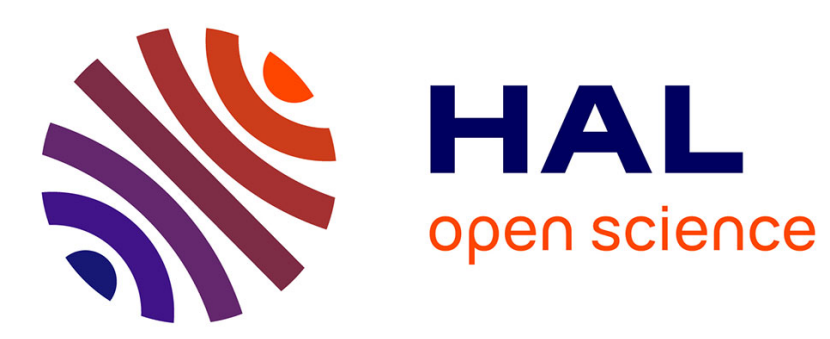

\title{
Direct and indirect effects of FDI in emerging European markets : a survey and meta-analysis
} Jan Hanousek, Evžen Kočenda, Mathilde Maurel

\section{To cite this version:}

Jan Hanousek, Evžen Kočenda, Mathilde Maurel. Direct and indirect effects of FDI in emerging European markets: a survey and meta-analysis. 2010. halshs-00469544

\section{HAL Id: halshs-00469544 \\ https://shs.hal.science/halshs-00469544}

Submitted on 1 Apr 2010

HAL is a multi-disciplinary open access archive for the deposit and dissemination of scientific research documents, whether they are published or not. The documents may come from teaching and research institutions in France or abroad, or from public or private research centers.
L'archive ouverte pluridisciplinaire HAL, est destinée au dépôt et à la diffusion de documents scientifiques de niveau recherche, publiés ou non, émanant des établissements d'enseignement et de recherche français ou étrangers, des laboratoires publics ou privés. 


\section{Documents de Travail du Centre d'Economie de la Sorbonne}

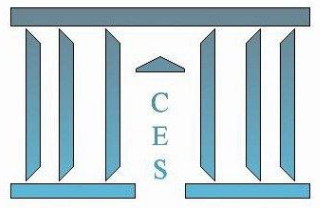

Direct and Indirect Effects of FDI in Emerging European Markets : A Survey and Meta-analysis

Jan HANOUSEK, Evžen KočENDA, Mathilde MAUREL

2010.24

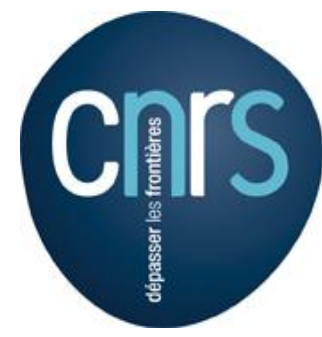




\title{
Direct and Indirect Effects of FDI in Emerging European Markets:
}

\section{A Survey and Meta-analysis}

\author{
Jan Hanousek $^{a}$, Evžen Kočenda ${ }^{b}$ and Mathilde Maurel ${ }^{c}$
}

\begin{abstract}
We review a large body of literature dealing with the effects of Foreign Direct Investment (FDI) on economies during their transformation from a command economic system toward a market system. We report the results of a meta-analysis based on the literature on externalities from FDI. The studies on emerging European markets covered in our survey report direct and indirect FDI effects weakening over time, similarly as in other FDI destination countries. This is imputable to a publication bias that is detected and to the fact that more sophisticated methods and more controls can be used once a sufficient time span is available. Panel studies are likely to find relatively lower spillover effects. The choice of the research design (definition of firm performance and foreign firm presence) matters. More specific to the sampled studies is the role played by forward and backward linkages, which dominate other channels in driving FDI externalities.
\end{abstract}

Keywords: FDI; productivity spillovers; economic transformation; emerging markets; metaanalysis

JEL classification: C42, D62, F21, F23, O3

a CERGE-EI, Charles University and the Academy of Sciences, Prague, Czech Republic; Anglo-American University, Prague; The William Davidson Institute, Michigan; and CEPR, London. E-mail: jan.hanousek@cerge-ei.cz.

b CERGE-EI, Charles University and the Academy of Sciences, Prague, Czech Republic; Anglo-American University, Prague; CESifo, Munich; The William Davidson Institute, Michigan; CEPR, London; and the Euro Area Business Cycle Network. E-mail: evzen.kocenda@cerge-ei.cz.

c CES, University of Paris I, 106-112 Blvd de l'Hopital, 75013 Paris, France. Chaire de Finance Internationale. E-mail: mathilde.maurel@univ-paris1.fr.

For helpful comments we are thankful to Jarko Fidrmuc, Renáta Kosová, Nargiza Maksudova, Brano Saxa, and Anastasia Shamshur. While preparing this paper Hanousek and Kočenda benefited from GACR grant No. 402/091595. The usual disclaimer applies. 


\section{Introduction}

The European economies that have undergone a transformation from a command system towards a market system offer a rich basis for evaluating the increasing importance of multinational companies (MNCs) and of the associated Foreign Direct Investment (FDI). The experience of these countries foster many insights that can be generalized to other emerging economies. On the macroeconomic level, the transformation process produced a dramatically higher degree of openness. From a microeconomic perspective, privatizations in a number of forms created new ownership structures and impacted economic performance in varied ways, as evidenced in Estrin et al. (2009). A completely new environment characterized by new institutional rules, new incentives and the willingness to engage in and benefit from international competition opened for those countries. Emerging European economies began benefiting from international experience, know-how, and integration into international networks of production and trade. The countries that opened their economies more widely to FDI reaped more gains and successes from the transition process.

At the beginning of the transition process the countries exhibited a great degree of heterogeneity and opted for different transition paths, all of which involved opening up to international trade and capital. The consequences of the different strategies show in the overall productivity levels. One can disentangle whether higher competition on internal markets faced by domestic firms when confronted with very powerful international companies caused the expected output in terms of improved access to markets, effective transfers of technology and know-how, and bringing domestic firms closer to the production frontier. Were domestic firms too weak to compete in this new context? Were they crowded out? A recent report by the World Bank (2006) distinguishes two sets of countries. The first set contains the geographically delimited Central and Eastern European countries (CEECs) and also includes Baltic and Balkan countries. The second set contains the countries belonging to the Commonwealth of Independent States (CIS). The CEECs, in a more or less radical way, implemented new market institutions, opened up to trade and capital, and made the necessary institutional steps for entering the EU. In contrast, the CIS countries opted for more gradualist approaches. The heterogeneity of results allows an assessment of the impact of trade and production integration, the impact of research and development (R\&D), absorption capacity, and institutions on FDI efficiency and externalities.

The policy implications that can be drawn from the transition experience are meaningful. When advocating the need for state aid provisions to foreign investors, there are 
two major benefits that are emphasized by policymakers: direct effects on the productivity of firms receiving foreign investment and spillovers produced by foreign-owned firms and positively affecting local firms. Being able to track these effects to see whether they are significant at the empirical level is of great importance. From that respect this paper focuses on the direct and spillover effects due to the presence of MNCs and FDI. There are also other channels of spillovers, like the exposure to international trade and R\&D activities (see Damijan et al., 2003b and Kočenda et al., 2009). Further, while the majority of studies analyze FDI impact using production functions, Kosová (2009) employs a model that combines a dominant firm-competitive fringe framework and a model on firm and industry dynamics. Her results (on Czech data) show evidence of both technology spillover and crowding out effects suggesting that crowding out, and thus adjustment of domestic firms to FDI inflows, is just a one-time static effect realized upon foreign entry.

In any event, the findings in the current FDI literature that target post-transformation economies in Central and Eastern Europe and the CIS produce evidence that is frequently inconclusive due to various biases. Therefore, we perform a meta-analysis to show that while direct effects are on average present, there is some dispute over the evidence for spillover effects. The research design matters: there seems to be a publication bias and later studies report less evidence for spillover effects. Also, the specificity of the transition experience may rely on the importance of forward and backward linkages in driving positive externalities. As emphasized by Kinoshita (2000) and Damijan et al. (2003a), among others, education and R\&D channels are less conclusive.

The remainder of this paper is structured as follows. Section 2 presents some stylized facts. Section 3 covers the basic definitions, introduces the baseline specification that constitutes the basis for the meta-analysis, and lists the major econometric problems encountered in the analysis of spillovers. Section 4 presents the sample of studies through a review of the literature and section 5 displays the results of the meta-analysis. Section 6 summarizes the main results and suggests some conclusions.

\section{Overview of trends and stylized facts}

According to Stiglitz (2000, p. 1076), "the argument for foreign direct investment is compelling. Such investment brings with it not only resources, but technology, access to markets, and (hopefully) valuable training, an improvement in human capital. Foreign direct investment is also not as volatile - and therefore as disruptive - as the short term flows." Multinational companies and the associated FDI are indeed an indisputable factor of growth 
in emerging and developing countries and they constitute a major driving force of globalization, despite the recent trend reversal due to the financial crisis. Up to the year 2007, the year in which a record global FDI inflow of USD 1.9 trillion was reached, transition countries were the second most important destination market for FDI, the first being emerging Asia. While it is sometimes argued that FDI are mostly efficient in some fairly advanced and large host countries (see Mayer-Foulkes and Nunnenkamp, 2009), even Africa benefited from this general increase in FDI (see Table 1). Strong economic growth in most of the OECD and emerging markets during recent decades was driven by high commodity prices and the good performance of equity markets. However, the situation changed dramatically after the global financial crises of late 2008. Global FDI declined in 2008 and 2009 by $17 \%$ and 35\%, respectively (Kekic, 2008).

For transition economies specifically we observe a continuous trend of increasing FDI over the period 2000-2007 (see Figure 2). Similar to most developing countries, 2007 was a record year with a total inflow reaching USD 158.5 billion into transition countries. Similar to other regions in the world, transition countries did not escape the negative consequences of the global financial crisis starting in 2008. As reflected in Figure 2, FDI in percent of GDP ranged between 4 and 5\% of GDP over the period 2004-2007, and this percentage drops to less than $3 \%$, a figure lower than in 2000 . The decline is limited by a strong exchange rate to the dollar, competitive labor costs as compared with the EU-15, and EU membership even though this is often over-emphasized. However, there are negative factors hampering FDI prospects in some countries: political instabilities, disputed borders, and weak states in the Balkans.

\subsection{FDI, trade and international production networks}

Strong FDI inflows in transition countries were driven first by massive privatization, reinvested earnings, a real estate boom, commodity investments in some CISs and a very strong FDI influx into Russia. According to the World Bank (2006), these inflows induced technological and organizational spillovers, which changed the economic landscape facing industries and firms. FDI has been a key agent in the transformation from planned towards market economies, through the creation of international production and trade networks.

Production sharing and spillovers have been growing, therefore, mainly in CEECs, while most CIS countries have been left out of the process. The countries being integrated into the networks benefited from bigger amounts of FDI: Tajikistan received only USD 46 of 
FDI per capita by the end of 2008, while the corresponding figure for Estonia is 14 times higher, standing at USD 652 (see Table 2).

The shift of CEECs from unskilled-labor-intensive exports (clothing and furniture) to capital-intensive exports (automotive and information technology industries) was driven by sizable inflows of FDI and can be attributed to a better integration of the recipient countries into the EU15-based networks of production. Figure 3 shows the contrast between Central European countries and Eastern European countries, which lag behind (see Lefilleur and Maurel, 2009).

With the progress from transformation, the transition countries became more open and engaged in international trade. As a majority of MNCs engaging in FDI produce for export, the openness has further strengthened. Commodities are produced by market-seeking investors and then re-exported towards EU-15 markets.

\subsection{FDI and institutions}

The FDI impact on CEECs is one piece of an emerging market success story. According to the World Bank (2006), EU-15 investors constituted more than 80\% of CEE's inward FDI, of which half was invested into services. As a result of this massive foreign investment, the region attained rapid growth in productivity and exports, developed a financial sector, upgraded infrastructure and skills, and speeded up structural reforms. FDI proved to be very efficient in restructuring the recipient economies.

As emphasized by the World Bank (2006), there is indeed a strong link between FDI and market-oriented, open-trade policy regimes: a well-developed trade facilitation system, modernized service sectors (such as transport and communication infrastructure), and trade and financial services are important determinants of FDI. Further, liberalizing services such as banking, telecommunications, and transport allows the growth of service exports. More importantly, higher standards of governance (as implemented under EU enlargement, for instance) or the adhesion to labor rights (see Busse, Nunnenkamp and Spatareanu, forthcoming) attract bigger FDI inflows and better quality investment. According to Campos and Kinoshita (2010), one key reform for attracting FDI is financial reform, which benefits the network of suppliers foreign firms need to succeed in the host economy by allowing the success of backward linkages. It is also widely agreed that a higher level of corruption hinders growth through its impact on FDI (see Hellman, Jones and Kaufman, 2002).

\section{Measurement of FDI effects and econometric issues}


The impact of FDI presence is stronger if it produces effects beyond the enterprises where FDI take place. In other words, it is stronger if the FDI can be translated into direct as well as indirect (spillover) effects. According to most of the empirical findings, the direct effects of FDI are quite straightforward and are reflected by new capital, technology and know-how. The impact of direct effects are mostly studied on productivity, usually measured as a change in Total Factor Productivity (TFP) or the labor productivity of the firm entered by the foreign investor. The indirect effects of FDI are externalities (i.e. spillovers) to domestic companies and industries and we review its essential forms presently.

FDI spillovers can be divided into horizontal and vertical. Horizontal spillovers are externalities to domestic companies at the intra-industrial level. The entry of a company whose productivity is driven by FDI encourages other companies within the same sector to catch up in terms of performance and competitiveness. An increase in efficiency can happen by copying new technologies or by hiring trained workers and managers from foreign-owned companies (Javorcik, 2004). In contrast, vertical spillovers occur at the inter-industry level, as in the case of technology transfers to domestic suppliers or customers in the production chain. Companies operating in other sectors than the foreign enterprise are affected by the FDI presence if they are in direct business contact with it through the supply and provision of services. In most cases foreign companies require higher standards from their suppliers and customers, including domestic companies. The efficiency of these domestic companies therefore increases.

A spillover effect can be negative but it should not be always attributed to the lack of absorptive capacity of domestic firms in less developed countries. It is rather a finding of "no" spillovers (i.e. a lack of spillovers) that is likely driven by missing absorptive capacity. A negative FDI impact should be rather attributed to competitive effects out-weighting any potential positive spillover effects. The larger the technology and human capital gap between domestic and foreign firms, the less likely domestic firms are to gain from the spillovers. This is called the "gap" problem in the literature (Abramovitz, 1989; Fagerberg, 1994; Gorodnichenko, Svejnar and Terrell, 2006). Positive spillovers are found therefore in more technologically advanced sectors or in more industrialized countries. There are other explanations behind negative spillovers. Foreign investors can pick the best local company, allowing that company to dominate the market and crowd out other firms. Alternatively, an investor can choose an industry with weaker local companies (Stancik, 2009). In either case negative horizontal spillovers can occur. If foreign investors operate in the exporting industry, they do not have to care about local companies within the same sector as they can find good 
suppliers and concentrate on exporting. This may result in positive horizontal and backward spillovers.

It is important to distinguish between "takeovers" and "greenfields". Takeovers usually start by improving the acquired company's organization and management; new technologies may arrive much later. Moreover, they are likely to use the existing network of suppliers and customers. In contrast, greenfields often bring in state-of-the-art technologies immediately and may not use local markets at all (Stancik, 2009).

Another type of effect connected with FDI is technology transfer. Blomström and Kokko (1998) distinguish three main channels for technology transfers through FDI. The first channel is competition. According to Blomström (1992), the entrance of foreign enterprises contributes to progression on industrial, technological and managerial levels. Placed in a more competitive environment, firms export more. Or in the opposite way, MNCs may induce crowding-out effects and unfair competition, which generates harmful externalities to domestic firms. Aitken and Harrison (1999) first pointed to a "market-stealing" effect as a reason for finding the negative impact from FDI when searching for spillovers in Venezuela. Later, Haddad and Harrison (1993) tested these unwanted effects and reported evidence of such negative horizontal spillovers. The second channel is the demonstration of differences in technology between foreign investors and host-country firms. MNCs enter the host country market and establish affiliates that possess better technology compared to the local firms' technology. The local firms watch and imitate these affiliates in the same industry, thus becoming more productive. The third channel is labor turnover. The host country's citizens employed by the foreign investor might benefit from contact with the new technologies and production methods. The transfer of human capital, knowledge, and skills toward the host country labor force enhances the competitiveness of domestic firms. MNCs train the local labor force, which is cheaper than importing skilled labor from their home countries, even though, in most cases, they cannot prevent a high labor turnover (Gorg and Greenaway, 2004).

To quantify the above direct and indirect effects, most of the empirical studies employ following baseline model:

$Y_{i t}=f\left(X_{i t}\right)+g\left(G_{i t}, Z_{i t}\right)$,

where Yit is an indicator of the firm's economic performance. The performance can be labor productivity, estimated as real value added per worker (sectoral version applied by Barrel and 
Holland, 2000; firm-level version in Schoors and van d. Tool, 2000), revenue, employment and cost per unit of revenue (Frydman, Gray, Hessel and Rapaczynski, 1999), output growth, TFP, etc. Further, Xit denotes the determinants of this performance, such as inputs, capital and labor, human capital, institutions, EU membership agenda, infrastructure, etc. Then, Git stands for factors that produce direct effects, i.e. foreign ownership, majority foreign ownership, or R\&D expenditures of the firm measured as a ratio to total sales. Finally, Zit stands for spillovers stemming from the presence of foreign firms, i.e. the employment share in foreign-owned firms, foreign output or the value-added share, the share of assets held by foreign firms, or the share of sales by foreign firms.

\section{Econometric issues}

\subsection{FDI measurement}

TFP is employed as a measure of firm productivity in most of the studies. Its measurement can be biased by a problem of simultaneity, arising from the fact that a firm may observe (part of) its productivity before the choice of inputs is made. Such a firm can then adjust the inputs according to the observed productivity, which in the case of OLS estimation results in a bias due to the correlation between the error term and the regressors. To correct for this simultaneity problem, the approach of Olley and Pakes (1996) is employed by Evenett and Voicu (2001) and Javorcik (2004). A similar way to correct for simultaneity proposed by Levinsohn and Petrin (2003) is employed by Javorcik and Spatareanu (2003). Damijan et al. (2003b) use a system GMM estimator and Konings (2001) applies a difference GMM estimator.

\subsection{Estimation biases}

When estimating the effect of foreign presence on the productivity of domestic firms various biases may arise.

Aggregation bias: In most cases, no data at the firm level is available, which leads to estimation at the aggregate level, i.e. by province or industry. An important assumption in the FDI spillover literature is that foreign-invested firms have better technology that spills over to domestic firms through various channels. Thus, it is assumed that firms with foreign investment are more productive than firms without foreign partners. In studies that use aggregate data, foreign firms are frequently not excluded from the aggregates. In this way the estimates of spillover effects obtained from aggregate regressions are subject to an upward 
aggregation bias. Aggregation bias can be avoided by excluding foreign firms from the aggregates or by using firm-level data (Hale and Long, 2007).

Selection bias: This issue can be divided into two categories: sample-selection bias and self-selection bias. Estimating the model on a subsample of domestic firms or using aggregates that exclude firms with foreign investment is not without flaws as sample-selection bias is present. ${ }^{1}$ On other hand, decisions of foreign investors about the choice of firms to enter are unlikely to be random, meaning that a simple comparison of productivity between firms owned by domestic and foreign owners involves a self-selection bias. Both issues are interconnected to a degree. Consider for example that FDI takes place as a merger and acquisition rather than a greenfield investment. Foreign firms choose to invest in domestic firms that are more productive ex ante (i.e. the "cherry-picking" phenomenon), as opposed to investing at random and making firms more productive ex post. In this way, firm-level crosssection regressions that are limited to domestic firms yield estimates of productivity spillovers of FDI that are biased downward if "cherry-picking" is present. The same is true for aggregate analysis that excludes foreign firms from the aggregates. Zajc (2006) analyses a firm's probability of exiting. He emphasizes that foreign entrants are more productive than the average firm and they exit more frequently, particularly those entering in the form of acquisitions. He shows that the least efficient firms experience a drop in their survival probability upon the entry of a foreign firm, and that foreign firm entry stimulates a selection process not only within the industry but also through backward linkages in upstream supplying industries. Moreover, there is more evidence of vertical than horizontal productivity spillovers from foreign firms. In this respect Zajc (2006) and Kosová (2009) found exactly the same results, i.e. a negative impact from FDI entry on the survival of the Czech firms but positive spillovers afterwards.

Sample-selection bias can be addressed by estimating a model of sample selection, which allows for the selection of the firms into domestic and foreign categories to be correlated with the firm's productivity. Of course, this approach requires firm-level data, including data on firms with foreign investment. The Heckman (1979) selection model can be employed, using, for example, a maximum likelihood estimation of two simultaneous equations. However, caution has to be adopted as the Heckman two-step methodology is directly applicable only when working with cross-sectional data. Use of the Heckman sampleselection methodology with panel data might be difficult for two reasons: (i) Calculating

\footnotetext{
${ }^{1}$ Vahter (2004) shows the presence of sample selection bias in the Slovenian case, but not in the Estonian case.
} 
Mills' ratio while taking into account repeated observations per unit of analysis (i.e. panel) would be very complicated and traditional software packages are not designed deal with such a situation. ${ }^{2}$ (ii) It is not possible to control for firm fixed effects in the traditional way via data de-meaning that is often desired to estimate the second stage structural equation. The first stage equation in the Heckman's approach relies on probit estimation but there is no "fixed effects probit". In sum, trying to control for "sample-selection bias" by employing the Heckman methodology might not deliver reliable results when working with data sets containing a time dimension.

Self-selection bias or "cherry-picking" seems to be an even bigger problem than sample-selection. For example, foreign firms may target more efficient domestic firms or industries to enter, or the most efficient domestic firms are able to benefit from spillovers. The need to control for such an unobserved firm efficiency level or self-selection can be resolved by collecting panel data and controlling for firm fixed effects. The "cherry-picking" phenomenon is recognized in most of the empirical papers. For instance in Evenett and Voicu (2001)'s benchmark model all sectors are together and use a balanced panel (i.e. only firms that occur in the data every year over the selected period are used), and Heckman's two-step estimation is employed to correct for selection bias. To explain the choice of investors, the financial data of firms from the year preceding the beginning of the sample period are used. The authors find that foreign investors tend to choose the largest and most successful firms. Heckman's two-step method is also used by Djankov and Hoekman (2000) who suggest that investors are more interested in acquiring firms with higher initial productivity. In contrast, Damijan et al. (2003b), using the same method, find that size is insignificant in all countries and that labor productivity is significant in only two out of ten countries. They find capitaland skill-intensive firms to be preferred in seven countries. In addition, they show that foreign investors tend to enter industries that already have a high concentration of foreign owners. Similar conclusions are suggested in Damijan et al. (2003a), who find that in Estonia and Slovenia, the perspective for export plays an important role in the decisions of foreign investors.

Endogeneity: This problem leads to an upward bias in the estimates of the productivity spillover of FDI. The best way to address this problem is to estimate a fixed-effect or difference-in-differences model with individual firm fixed effects (Hale and Long, 2007). One must also ensure that the panel includes a large enough time span because FDI do not vary

\footnotetext{
${ }^{2}$ Calculating Mills' ratio based on, say, only the first or the last observation of the panel is incorrect.
} 
much over time. Alternatively, an instrumental variables approach can be used through employing 2SLS or GMM. When an independent set of instruments is not available the Arellano and Bond (1991) technique is used: this methodology is applicable only when estimating the dynamic panel equation with fixed effects; i.e. when the lagged dependent variables are included among regressors. ${ }^{3}$ However, this method is not generally applicable, as is 2SLS or GMM, to resolve traditional endogeneity (or simultaneity) problems (i.e. when the lagged dependent variable is not among the regressors). An example can be found in Halpern and Muraközy (2005) who address the endogeneity bias by employing the ArellanoBond (1991) dynamic panel data technique. They analyze horizontal and vertical spillovers through FDI in Hungary using a panel of 24,000 firms. There are significant horizontal and backward spillovers for domestic-owned firms that imply benefits from foreign competitors and customers. In contrast, the effect of regional and county boundaries is not significant. The authors further estimate the spatial structure of spillovers: for domestic firms the foreign presence matters only over a small distance $(25 \mathrm{~km})$, while for foreign-owned firms, the longer the distance, the stronger the spillover (50 and $100 \mathrm{~km})$.

Downward bias in standard errors: Since the measure of FDI presence is, by definition, an aggregate measure, one must deal with the potential correlation of standard errors in firm-level regressions (Moulton, 1990). If the standard errors are calculated based on the assumption of i.i.d. disturbances, they will be biased downward, mistakenly leading to a conclusion that the estimates are statistically significant even if they are not. This problem can be easily remedied by computing robust standard errors clustered on industry $i$ (Hale and Long, 2007).

\section{Review of the literature}

In this section, we describe the major findings, techniques and data used in papers that estimate the importance of both direct and indirect effects of FDI in transition countries.

\subsection{Review of the empirical literature: Direct and spillover FDI effects}

\section{Direct Effects}

\footnotetext{
${ }^{3}$ It should be noted that Arelano-Bond (1991) technique tends to suffer from serious biases when most of the panel variation comes from the "fixed effect " as opposed to "idiosyncratic-error" type of variation, or when coefficient of the autoregressive component (i.e. lagged dependent variable) tends to be close to one as discussed by Blundell and Bond (1998). Hence, implications of studies using Arelano-Bond (1991) technique should be interpreted with a caution.
} 
In terms of the direct effects of FDI, the majority of empirical findings are conclusive that foreign presence is associated with a better performance of domestic enterprises. A summary of the findings is provided in Table 3. Some studies analyze direct FDI effects in the context of a single country. The Czech Republic case is studied in Djankov and Hoekman (2000), who report that benefits are larger when investment comes in form of FDI rather than a joint venture, and in Evenett and Voicu (2001), who argue that the estimated positive effects of FDI on performance are in some cases unrealistically high, and that the lack of suitable variables leads to an unsatisfactory estimation of self-selection. Using a data set of Hungarian firms, Sgard (2001) shows that firms with foreign ownership outperform domestic firms.

In terms of empirical analysis, most of the papers focus on more than one country, for comparison and generalization purposes. For instance, Konigs (2001) analyzes firm-level data from Romania, Bulgaria and Poland, and confirms that firms with some foreign investment perform better than firms without foreign participation. Damijan et al. (2003a) and Damijan et al. (2003b) provide comparable estimates of the impact of FDI on productivity for seven and ten CEE countries, respectively. Damijan et al. (2003a) controls for selection bias and distinguishes between spillovers occurring through innovative and absorptive capacity and spillovers occurring through trade. Their results suggest that direct effects constitute an important channel for technology transfer in five out of eight countries: the Czech Republic, Estonia, Poland, Romania and Slovenia, while the impact of FDI is not significant in Bulgaria, Hungary and Slovakia. ${ }^{4}$ The effect of majority foreign ownership turns out to be insignificant in all eight countries. Damijan et al. (2003b) confirms that the effect of FDI is mixed: significant and positive in Hungary, Estonia and Slovenia, and significant and negative in the Czech Republic and Poland. In Lithuania and Romania, firms with foreign ownership perform significantly worse, however, an additional dummy on majority FDI is negative (and the total effect of foreign ownership and majority foreign ownership is in both cases negative, too). It is interesting to note that the differences between the two papers may be imputable to different estimation techniques, and to the fact that the specifications to be estimated are slightly different.

Two studies focus on labor productivity instead of TFP as a measure of productivity. Vahter (2004) examines the effect of foreign ownership on the ratio of sales and employees in Estonia and Slovenia. Besides the finding that foreign-owned firms are more productive than their domestic counterparts in both countries, the authors look at the differences between

\footnotetext{
${ }^{4}$ However, this is attributed to poor data quality in case of the latter two countries.
} 
exporting and non-exporting firms. In Estonia, export-oriented foreign-owned firms are less productive, while the opposite result holds for Slovenia. In the only surveyed study that uses industry-level data, Barrel and Holland (2000) examine the effect of foreign ownership on labor productivity, e.g. the total employment in a sector relative to the real value-added in the sector. The countries covered are the Czech Republic, Hungary and Poland. It is shown that the presence of FDI is positively correlated with labor productivity. After controlling for FDI, private ownership does not increase labor productivity.

\section{Spillover Effects}

Spillover effects are interpreted as a transfer of knowledge and technology from a foreignowned firm to local firms. The presence of spillovers is empirically studied either on the intraindustry level (horizontal spillovers) or the inter-industry level (vertical spillovers). The variable of interest is the concentration of foreign investors in the same industry (horizontal) or in the upstream/downstream industry (vertical). A summary of the empirical findings on FDI spillovers is reported in Table 3. Contrary to the direct effects of FDI on performance, the indirect effects are not clear-cut: the results differ according to the country or period analyzed and the econometric methodology.

The estimation of spillover effects, in contrast to direct effects, requires special attention to the specifics of the FDI transfer mechanisms, such as:

i. MNCs invest in more profitable firms (selection bias), an issue which has been investigated with special emphasis in all transition countries. This bias can be controlled for in panel data analysis (as discussed in Section 3.2).

ii. The crowding-out effect: foreign firms have a higher production technology and lower marginal costs, and attract demand away from domestic firms. Productivity decreases (at least in the short run) because of competition.

iii. Spillovers occur only in certain sectors (with high $R \& D$ ). Blomström and Kokko (1998) find evidence of productivity spillovers only to domestic firms with a moderate technological gap (the capability of making use of the spillover effects).

iv. Negative spillovers are characteristic for the early period, when crowding-out effects dominate competition and demonstration effects. Local firms lose market share and skilled employees are captured by foreign-owned firms. Later, positive spillovers are more likely to occur.

v. Foreign owners have an incentive to prevent the leakage of knowledge and technology to local competitors (in the same industry), but they may profit from improvements 
on the side of their suppliers (backward linkages). Also, local firms may benefit from using better intermediate input produced by the foreign-owned firm (forward linkages). The idea of searching for positive vertical spillovers instead of horizontal spillovers was applied by Javorcik (2004).

There are several studies that cover the spillover effects in multiple transition countries. Damijan et al. (2003a) report no significant horizontal spillovers, except in Romania, even after controlling for absorptive capacity. On the contrary, Damijan et al. (2003b) suggest that horizontal spillovers to domestic firms are significant and positive although relatively small in the Czech Republic, Poland, Romania and Slovakia (out of the ten countries studied). The authors report significant and positive backward vertical spillovers to local firms in the case of the Czech Republic, Poland and Slovenia, but not in the other seven countries. Konigs (2000) finds no spillovers in Bulgaria and Romania and significantly negative spillovers in Poland. Vahter (2004) finds evidence of horizontal spillovers in Slovenia, but no horizontal spillovers in Estonia, which is in line with Vahter (2005). Javorcik and Spatareanu (2005) analyze firms' perceptions in the Czech Republic and Latvia. In the Czech Republic (Latvia) 48\% (41\%) of respondents believed that the entrance of foreignowned firms increased competition in the sector, while 29\% (29\%) indicated they lost market share. Positive spillovers are reported in the Czech Republic (Latvia) by 25\% (15\%) of the firms that adopted new technologies and 12\% (9\%) of the firms that observed marketing techniques. In a recent detailed country study Ayyagari and Kosová (2010) find that a larger foreign presence in the Czech Republic stimulates the entry of domestic firms within the same industry (positive horizontal spillovers from FDI). They also find evidence of significant vertical entry spillovers-FDI in downstream (upstream) industries initiates entry in upstream (downstream) sectors. Vertical spillovers are found stronger than horizontal ones that are driven by FDI from the EU countries.

Tytell and Yudaeva (2006) focuses on the four most populous countries of Eastern Europe: Russia, Ukraine, Poland, and Romania. The authors demonstrate that positive spillovers occur only in the case of export-oriented FDI and that they are driven by more productive foreign companies. They report evidence of threshold effects: benefits are more likely to materialize when a larger stock of foreign capital is accumulated. Also the absorptive capacity of domestic firms plays a crucial role in reaping the benefits of FDI. Finally both knowledge spillovers and an improvement in production technology occur predominantly in the more educated and less corrupt regions. 
Franco and Kozovska (2008) test the presence of traditional direct horizontal and reverse horizontal spillovers in Poland and Romania. The authors introduced the novel concept of regional clusters and examined two hypotheses: (1) whether the direct spillover effect is greater for firms in clusters compared to non-clustered firms and (2) whether the reverse spillover effect actually takes place and if clusters have any impact. For estimation procedures the authors employed data on more than 7000 manufacturing firms and compared OLS in first differences with dynamic GMM model specifications. The results support the evidence of positive cluster effects, and in particular there are reverse spillover effects found both in clusters and outside clusters. The implication of these results is that the presence of clusters is a determinant of FDI localization decisions since there is a chance of reverse spillovers even if the host country does not possess a higher technological capacity.

In their recent paper Damijan, Rojec, Boris and Knell (2008) employ the largest data set so far (more than 90,000 firms) in ten transition countries: Bulgaria, the Czech Republic, Croatia, Estonia, Latvia, Lithuania, Poland, Romania, Slovenia and Ukraine. From a methodological point of view the authors control for various sources of firm heterogeneity, and provide a correction for selection and simultaneity. The results suggest that horizontal spillovers have become increasingly important over the last decade and could become more important than vertical spillovers. Firm heterogeneity (i.e. absorptive capacity, size, productivity and technology levels) matters while firms with higher absorptive capacities are capable to both compete with foreign affiliates in the same sector and benefit from the increased upstream demand for intermediates generated by foreign affiliates. Finally, FDI presence could affect smaller firms to a greater extent than larger firms; this impact, however, may be in either direction.

Most of the papers analyzing spillover effects focus on a single country. For the Czech Republic, Djankov and Hoekman (2000) reports evidence of significant and negative horizontal spillovers for both FDI and joint ventures. Kinoshita (2000) finds that horizontal spillovers are limited to local firms involved in R\&D. Stančík (2007) employs firm-level panel data from 1995 to 2003 and studies horizontal/vertical spillovers. The paper considers lagged spillovers and pays attention to the endogeneity of FDI with respect to future industry growth. The results indicate that domestic firms suffer the most from the presence of foreign companies, and the effect is more acute in upstream sectors. Horizontal and vertical spillovers are negative and present mainly in recent years while time sensitivity is revealed for horizontal spillovers. In a later study Stančík (2009) extends his previous paper by distinguishing two types of foreign investment: takeovers and greenfields. He finds that the 
impact through horizontal spillovers is mixed: positive from foreign takeovers and negative from greenfields. Forward spillovers are positive and present mainly in recent years while time sensitivity is revealed for both horizontal and vertical spillovers.

For Poland, Kolasa (2007) uses an unbalanced panel of firms' balance sheets and profit-and-loss statements for the period 1996-2003, with a total of 147,479 observations. The results are manifold. There is a positive benefit for local firms from FDI in the same downstream industries, and the absorptive capacity of domestic firms, measured by their investment in R\&D, matters. Finally, higher competition facilitates spillovers from FDI in downstream industries. The main policy implication, in line with Blomstrom and Kokko (2003), is to support policies aimed at strengthening the absorptive capacity of domestic firms. Golejewska (2009) used unbalanced panel data for 103 manufacturing industries during 1993-2006. By estimating two-way fixed effect and two-way random effect panel data models, he reports no significant positive productivity spillovers from FDI. This result can be compared with the previous findings of Zukowska-Gagelmann (2002) for 1993-1997 and Ciolek and Golejewska (2006) for 1993-1998 for all Polish manufacturing firms. Using the same methodology they find significant negative productivity spillovers. The authors consider that the following factors can explain the lack of positive spillovers: the firm's size, the sectoral distribution of FDI, the insufficient investment into R\&D by local firms, and heterogeneity across industries.

For Hungary, Sgard (2001) finds positive spillovers and shows that export-oriented foreign-owned firms produce more spillovers, suggesting this could stem from the fact that such firms do not compete with local firms. In addition, Sgard finds spillovers more pronounced in regions close to the EU border. For Estonia, Sinani and Meyer (2004) indicate that labor- and sales-intensive foreign-owned firms generate larger spillovers than their equity-intensive counterparts. Also, small firms, non-exporting firms and outsider-owned firms are more likely to benefit from the presence of a foreign-owned firm.

Romania is investigated by Javorcik and Spatareanu (2003), who find positive horizontal spillovers generated by firms fully owned by a foreign owner, but not by firms partially owned by foreigners. For vertical spillovers, the results suggest that firms partially owned by foreigners generate positive backward spillovers, while firms fully owned by foreigners generate negative backward spillovers. The latter is interpreted as the result of the different behavior of joint-venture investors who, unlike investors entering fully-owned greenfield investments, more often source intermediate inputs from local firms. The impact of structural breaks and environmental changes is emphasized in Schoors and Merlevede (2007), 
who focus on the period 1998-2001, when Romania experienced substantial structural changes. The authors separate out labor market effects from other effects in their identification of intra-industry spillovers, while inter-industry spillovers are identified through upstream, downstream, and supply-backward linkage effects. Schoors and Merlevede (2007) employ dynamic input-output tables to construct spillover linkages not only for manufacturing but for all industries. This is justified by the fact that the lion's share of foreign affiliates in Romania operate in the services sector. The results suggest that labor market effects differ from other intra-industry effects and spillovers across industries dominate those within industries. Supply-backward effects match the predictions of Findlay and the absorptive capacity hypothesis while the firm-specific level of technology, firm size and ownership structure affect spillovers.

For Lithuania, Javorcik (2004) finds no evidence of horizontal spillovers or vertical spillovers through forward linkages, however, there are significant and positive vertical spillovers through backward linkages. Those are generated only by firms partially owned by a foreign investor. Evidence of FDI impact for Ukraine is provided by Lutz, Talavera and Park (2008). The authors employed unpublished panel data from 1996-2000 to investigate the effects of a regional and industry-wide foreign presence on export volumes of domestic firms. The results suggest that FDI presence may have negative competition effects on domestic firms while productivity may be increased by technology transfer or through training and demonstration effects.

\section{Meta-Analysis}

As we showed in the preceding section there exists a considerable heterogeneity of empirical findings and inconclusive evidence on FDI spillover effects. In this section we run a metaanalysis, to summarize in a straightforward and quantitative way the main findings from this literature. Meta-analysis could shed more light on this issue and distinguish the reasons for such heterogeneity among publications, including publication bias, methodological issues, data availability and FDI measurement.

\subsection{Previous research}

Meta-analysis has not been used frequently in economics, because unlike fields such as psychology or medicine, economic research is usually not based on experimental data. Although one cannot argue that the transition is exactly like an experiment, the wide heterogeneity across transition countries in opening to foreign capital and learning from 
international experience created quasi-experimental conditions and outcomes to be analyzed. Such a meta-analysis is performed in Fidrmuc and Korhonen (2006) who focus on the business cycle correlation between the euro area and the CEECs.

In Table 3 we list the results of our literature search. In our meta-analysis we include papers that satisfy a combination of three criteria: they analyze direct effects, they analyze spillovers, and they cover emerging European markets (transition economies). We disregard studies that analyze only direct effects and also studies that use data about emerging/developing countries, but not transition countries. Altogether we cover 21 papers, which is the same number of studies used in the seminal work Görg and Strobl (2001).

Among the limited meta-analysis papers on FDI, Meyer and Sinani (2009) investigate the reasons for the results of mitigated FDI effects on local performance. The authors argue that cross-country differences may be driven by the use of aggregate versus firm-level data and cross-section versus panel data analysis, implying that the research design matters for the results. They report that spillovers are not found for industrialized countries in the 1990s, while transition economies may experience spillovers, though declining in recent years. Wooster and Diebel (2006) focus on developing countries. They conclude that spillover effects are more pronounced when studies measure the effect of FDI spillovers on output. Interestingly, they find that spillover effects are more likely to be more pronounced for Asian countries, and that spillover effects may be partly a product of model misspecification. Havranek and Irsova (2008) meta-analyze the literature on intra-industry productivity spillovers from FDI. Their findings suggest that cross-sectional and industry-level studies find relatively strong spillover effects, while the choice of a proxy for FDI is important. Papers published in leading academic journals tend to report rather insignificant results. Contrary to previous studies no publication bias is detected. Finally, a meta-analysis by Smeets (2008) reveals mixed evidence on the magnitude, direction, and even existence of knowledge spillovers from FDI. The results suggest that studies accounting for individual spillover channels find robust evidence of knowledge spillovers from FDI, and studies on the importance of mediating factors and FDI heterogeneity are less conclusive. Our meta-analysis delivers new results from a compact set of studies that satisfy three criteria. In this respect we offer new insights compared to studies that cover wide and heterogenous samples of papers.

\subsection{Methodology and findings}

We follow the seminal work of Görg and Strobl (2001), and run our meta-analysis on the sample of studies listed in Table 3. Our strategy is as follows. For a sample of studies on 
productivity spillovers and direct effects of FDI in transition countries, we collect the $t$ statistics on the two related foreign presence variables. We regress the t-statistics on a number of study variable characteristics: sample size, variable definitions used for foreign presence and definition of performance, and methodology used (cross section or panel).

The sample of papers analyzed here consists of 21 papers, 10 of which are published in academic journals, 6 are contributions to an edited volume (base category), and 5 are working papers (see Table 3 for a list of the studies included). To increase the number of observations, we follow the strategy used by Rose and Stanley (2005) in a meta-study about the impact of memberships into currency unions on international trade. We use all the estimates that are drawn from different specifications, variable definitions (horizontal/vertical spillovers, backward/forward spillovers, interacted with R\&D, FDI, etc.), or sub-samples. For instance in Damijan, Knell, Majcen and Rojec (2003a), we have two models, eight countries, and two definitions of the spillover effect, from which we obtain a total of 16 estimates.

Within the sample of studies we selected, some studies are concerned with measuring productivity spillovers in a sample of several transition countries, while others focus on one CEEC or CIS country separately. Most papers use panel data, except three (Schoors and Van der Tol, 2002; Yudaeva et al., 2003; Hellman, Jones and Kaufmann, 2002), which use crosssectional data. All observations are obtained from studies that use firm-level data.

In terms of the variable definitions, observations relate to foreign presence being measured as employment share, output or value added share, or other related measures. Performance is defined as labor productivity (output or value-added per worker), output growth, or TFP.

We estimate the following two specification:

$$
\begin{aligned}
& Y_{j}=b_{0}+\sum_{k=1}^{K} b_{k} X_{j k}+e_{j,} \quad j=1,2, \ldots N \\
& Z_{j}=b_{0}+\sum_{k=1}^{K} b_{k} X_{j k}+e_{j}, \quad j=1,2, \ldots N
\end{aligned}
$$

where $Y_{j}\left(Z_{j}\right)$ is the reported Students's t-statistic of the foreign presence variable, which measures the direct effect (FDI dummy equal to one if observation $i$ is a foreign firm) and indirect effect (proxy for the foreign presence measured by the foreign employment share in 
the sector where firm $i$ operates), in study $j$ from a total of $\mathrm{N}$ studies. Further, $X_{j k}$ are metaindependent variables that describe the characteristics of the empirical studies to explain the variation in the dependent variable across studies, as follows:

i. average trend of the study period (if the study covers the period 1994-1998, this variable will be equal to 2, that is, the mean of 1994-1998 minus 1994, which is the earliest starting date of our meta sample),

ii. separate dummies for the definition of the foreign presence (employment share $=1$, output/value added share $=2$, other $=3$ ),

iii. separate dummy variables for the definition of economic performance (output per worker is set equal to 1 , output growth is equal to 2 , other is equal to 3 ),

iv. dummy variables for the foreign presence variable interacted with $R \& D$, FDI or other related variables,

v. dummy variables for the nature of spillovers: horizontal, vertical backward $(V B)$, vertical forward $(V F)$, spillover variable interacted with Human Capital (a variable set equal to one when the firm receiving FDI spends on R\&D, on education, or is characterized by its high technological content; spillover variable interacted with FDI; spillover variable interacted with bribes),

vi. country dummies.

For the direct effects of FDI (Table 4), most studies find significant and positive effects of FDI on the performance of the firm entered by a foreign investor. The exceptions are two studies by Damijan et al. (2003a, 2003b), who find the direct effects to be insignificant or even negative in some countries. We run equation 2 on a sub-sample of studies where estimates of the direct effect were available. Our findings indicate that the evidence of a direct effect is weaker in Lithuania but higher in Estonia, Hungary, Slovakia, and the Czech Republic. We find that publishing in academic journals does make a difference, but this effect is not robust across specifications. We also find that the effect is lower when measured over a longer time span and that panel analysis, allowing taking into account endogeneity and simultaneity biases, reports a lower effect. Finally, measurement matters: direct FDI measured through labor productivity is higher.

In terms of spillover effects (Table 5), the choice of the proxies for both performance and foreign presence is an important factor behind the differences across studies. Performance measured as output growth and foreign presence measured by value-added share produce 
lower results relative to the benchmark cases (output per worker and employment share). This raises the question of how to properly measure the variables of interest.

Our findings suggest that studies using panel data report lower spillover effects. More recent data produce lower spillover effects, and papers published in academic journals tend to report lower spillover effects as well. The publication bias is confirmed by the test proposed in Görg and Strobl (2001), which consists of regressing the log of the absolute value of the tstatistics on the square root of the degrees of freedom. ${ }^{5}$ Publication bias might occur due to various factors. In particular, published works may have a larger amount of control parameters resulting in a smaller and less significant final effect. They are more likely to be concerned about endogenity and to try to treat it through the use of better estimation methods (instrumental variables or fixed effects). Finally, working papers and other sources (contributions in edited volumes) may be based upon more recent data, which translate into more pronounced effects of FDI, as the effects can indeed show up only at a later stage after FDI implementation and enforcement. Indeed, the average year of the data used in published papers in our sample is 1996. But for working papers the average year is 1997. Even more recent is the data coverage for contributions in other sources that are characterized by an average year of 2002. The results about the importance of the research design and the publication bias hold in other meta-analyses (see Wooster and Diebel, 2006; Meyer and Sinani, 2009 and Havranek and Irsova, 2008).

The literature indicates that the evidence for a spillover effect is weak. Two alternative explanations are behind this weak evidence. As emphasized in Gorodnichenko et al. (2006), the focus on horizontal spillovers may be one cause, ${ }^{6}$ while backward and forward linkages would be more prone to show unambiguously positive spillovers. In the case of vertical relationships, indeed there is no competition, but foreign firms are interested in improving the quality they get from their local suppliers (backward spillovers) as well as the quality of the domestic firms' inputs they purchase (forward spillovers). If the focus is on horizontal spillovers instead, two effects must be disentangled: (1) a crowding-out effect and (2) the improvement in efficiency due to proximity with more efficient producers. The net effect is likely to depend on the country and time considered, and it may be proportional to the firms' absorption capacity, measured through the amount of human capital available, R\&D, and the

\footnotetext{
${ }^{5}$ For the spillover effect the estimated coefficient is 0.483 , and the associated standard error is 0.048 . We can reject the hypothesis of the coefficient on the square root of the degrees of freedom being equal to one, which confirms that publication bias is present.

${ }^{6}$ While there are numerous studies on horizontal (intra-industry) spillovers, there are relatively few empirical studies on vertical spillovers. Two exceptions are notable: for Hungary Schoors and van der Tol (2002) and for Lithuania Javorcik (2004).
} 
sector involved. By taking into account the absorbing capacity, one should be able to demonstrate the existence of positive spillovers. In sum, positive externalities are more likely to occur in the case of vertical linkages or when the absorption capacity increases.

To see the importance of backward and forward linkages versus educational and technological gaps we run our meta-analysis by putting together or separating dummies for spillover types ( $V B$ for Vertical Backward and $V F$ for Vertical Forward) and spillovers interacted with educational/technological/institutional channels (human capital, FDI, bribes). Our results in tables 6 and 7 show that what matters is the presence of backward/forward linkages while more education or more R\&D does not favor spillover effects. The latter result is puzzling, as noticed in Gorodnichenko et al. (2006), amongst others.

The studies accounting for different spillover channels ( $\& \& D$, human capital, better reforms) do not find evidence of knowledge spillovers from FDI being more conclusive where the absorption capacity is higher. Kinoshita (2000) examines the two roles of the firm's R\&D (innovation and absorptive capacity). According to her results, the effects of FDI are significant only for firms that perform their own $R \& D$ (the horizontal spillover is positive and the direct effect is negative, whereas the effect of only $R \& D$ remains insignificant). Damijan et al. (2003a) find that intra-industry knowledge spillovers are insignificant, and that similarly to Kinoshita (2000), their significance increases when controlling for a firm's own R\&D. In a closely related study Damijan et al. (2003b) uses the sample of Damijan et al. (2003a), adds Lithuania and Latvia, and studies the period 1995-1999. In the case of horizontal spillovers, the new findings contradict the previous study, when the results claim the contribution of a firm's own R\&D is not confirmed to be significant. One can only assume that this inconsistency might be caused by either the different estimation approach (current GMM vs. previous OLS) or the shift in the time period.

The evidence in favor of vertical spillovers is stronger. Damijan et al. (2003b) for instance conclude that vertical spillover effects are present and they are more important than horizontal ones. Spillovers are therefore more likely to materialize through backward/forward linkages than through the absorption capacity ( $\& \& D$ and education linkage). This is consistent with Lefilleur and Maurel (2009) who analyze the role of inter- and intra- industry linkages in determining the localization of FDI in the CEECs. The authors emphasize a core-periphery structure within the CEECs, namely that Central European countries specialize in upstream industries and re-exporting goods toward FDI-origin countries, and Eastern European (periphery) countries are involved in this production chain but to a lesser extent. In the same vein, Gorodnichenko et al. (2006) extend the analysis of forward and backward spillovers to 
include the concept of selling or buying from firms outside of the country, i.e. importing and exporting. The idea is that vertical spillovers are concerned with linkages with foreign firms not only within the host country alone, but also with foreign trade partners. Similarly, Stancik (2007) stresses the importance of international production fragmentation by claiming that foreign investors tend to import their supplies from abroad rather than use domestic suppliers, while domestic companies oriented to the foreign market are able to use domestic suppliers.

\section{Conclusion}

This paper summarizes the broad range of empirical results on the direct effects and spillover effects of FDI drawn from 21 studies focusing on transition countries. Similar to other studies dealing with developing, emerging, and industrialized countries, we find that the research design is crucial for a proper analysis of productivity spillovers.

We provide evidence that there may be a publication bias. A longer time span can produce two opposite effects. FDI effects can benefit from having more time to show up, so one effect is positive. Therefore, higher reported spillover effects can be expected in more recent studies. The other effect is negative: the character of published studies, including the use of more sophisticated econometric methods, the treatment of all kinds of endogeneity problems, and controlling for time- invariant effects independent from FDI externalities but omitted in cross sectional studies, will tend to reduce the reported estimates. The negative effect tends to dominate the positive effect. In other words, more recent studies produce lower estimates.

Finally, we show that studies accounting for specific spillover channels (absorption capacity, $R \& D$, education, institutions) do not report evidence of knowledge spillovers from FDI, while studies accounting for the importance of FDI heterogeneity are not conclusive. In contrast, the importance of backward and forward linkages in producing spillovers is strongly acknowledged. This is a key result, which implies that local firms in transition countries experience efficiency gains if they supply industries with a higher share of foreign firms. Moreover, FDI must be encouraged where intersectoral linkages are more important. 


\section{References}

Abramovitz, M. (1989), Thinking about Growth, And Other Essays on Economic Growth and Welfare, Cambridge University Press, United Kingdom.

Aitken, B. and Ann E. Harrison. 1999. Do Domestic Firms Benefit from Direct Foreign Investment? Evidence from Venezuela. The American Economic Review, 89(3): 605-617.

Arellano, Manuel and Stephen Bond. 1991. Some Tests of Specification for Panel Data: Monte Carlo Evidence and an Application to Employment Equations, Review of Economic Studies, 58(2): 277-297.

Ayyagari, Meghana and Renáta Kosová. 2010. Does FDI Facilitate Domestic Entry? Evidence from the Czech Republic. Review of International Economics, 18(1): p 14-29.

Barrell, R. and Holland, D. (2000) "Foreign Direct Investment and Enterprise Restructuring in Central Europe." Economics of Transition 8(2)

Blomstrom, M. and Kokko, A. (1998). Multinational Corporations and Spillovers. Journal of Economic Surveys, 12(3), 247-77.

Blomstrom, M. and Kokko, A. (2003) "The Economics of Foreign Direct Investment Incentive", NBER Working Paper No. 9489.

Blundell, R. and Stephen Bond. 1998. Initial Condition and Moment Restrictions in Dynamic Panel Data Models. Journal of Econometrics, 87: 115-143.

Bosco, M. (2001) "Does FDI contribute to technological spillovers and growth? A panel data analysis of Hungarian Firms“, Transnational Corporations, Vol. 10, pp. 43-68.

Busse, M., Nunnenkamp, P., Spatareanu, M. (forthcoming), "Foreign Direct Investment and Labor Rights: A Panel Analysis of Bilateral FDI Flows", Applied Economics Letters.

Campos Nauro, Kinoshita Yuko, 2010, "Structural Reforms, Financial liberalization, and Foreign Direct Investment", IMF Staff Paper forthcoming

Ciolek, D., Golejewska, A. 2006. Foreign capital and its effects on investment outlays in Polish manufacturing in the first years of transition, 1993-1998. University of Gdansk, Department of Economics and European Integration, Working paper no. 4/2006.

Damijan, J., Knell, M., Majcen, B., Rojec, M. (2003a) “The role of FDI, R\&D accumulation and trade in transferring technology to transition countries: evidence from firm panel data for eight transition countries", Economic Systems 27 (2003) 189-204. 
Damijan, J., Knell, M., Majcen, B., Rojec, M. (2003b) “Technology Transfer through FDI in Top-10 Transition Countries: How Important are Direct Effects, Horizontal and Vertical Spillovers?”, William Davidson Working Paper Number 549, February 2003.

Damijan, J., Rojec, M., Boris, M. and Knell, M. (2008) "Impact of firm heterogeneity on direct and spillover effects of FDI: micro evidence from ten transition countries". Katholieke Universiteit Leuven, LICOS Discussion Paper No. 218/2008.

Djankov, S. and Hoekman, B. (2000) "Foreign Investment and Productivity Growth in Czech Enterprises". World Bank Economic Review, Vol. 14, pp. 49-64.

Estrin, S., Hanousek, J., Kočenda, E., Svejnar, J., 2009. Effects of Privatization and Ownership in Transition Economies. Journal of Economic Literature, 47(3), 699-728.

Evenett, S. and Voicu, A. (2001) "Picking Winners or Creating Them? Revisiting the Benefits of FDI in the Czech Republic?" Mimeo, the World Bank.

Evenett, S. and A. Voicu (2001), Picking winners or creating them? Revisiting the benefits of FDI in the Czech Republic, University of St. Gallen.

Fagerberg, J. 1994. Technology and International Differences in Growth Rates, Journal of Economic Literature, 32(3): 1147-1175.

Fidrmuc, J., Korhonen, I., 2006, Meta-analysis of the business cycle correlation between the euro area and the CEECs, Journal of Comparative Economics, 34(3), 518-537.

Franco, Ch. and Kozovska, K. (2008) "Mutual productivity spillovers and clusters in Eastern Europe: some empirical evidence". Available at SSRN: http://ssrn.com/abstract=1317334

Frydman, R., Gray, C., Hessel, M., Rapaczynski, A. (1999) "When Does Privatization Work? The Impact of Private Ownership On Corporate Performance In The Transition Economies". The Quarterly Journal of Economics, MIT Press, vol. 114(4), pages 1153-1191.

Görg, H. and Strobl, E. (2001) "Multinational companies and productivity spillovers: a metaanalysis" Economic Journal 111(475): pp. F723 - 39.

Görg, H., and Greenaway, D. 2004. Much Ado about Nothing? Do Domestic Firms Really Benefit from Foreign Direct Investment? The World Bank Research Observer, 19(2)

Gorodnichenko, Y. and Svejnar, J., Terrell, K. (2006) "Vertical and Horizontal FDI Spillovers in Transition Economies: Do Institutions Matter?”. University of Michigan 
Golejewska, A. (2009) "Productivity spillovers from Foreign Direct Investments in Polish manufacturing 1993-2006", Analizy i Opracowania KEIE UG 2/2009 (001), University of Gdansk.

Haddad, M. and Harrison, A.E., 1993. Are there positive spillovers from direct foreign investment? Evidence from Panel Data for Morocco, Journal of Development Economics 42 (1993), pp. 51-74.

Hanousek, J., Kocenda, E., Svejnar, J. (2007) "Origin and concentration: Corporate ownership, control and performance in firms after privatization", Economics of Transition Volume 15(1) 2007, 1-31.

Hale, G., Long, C., 2007. "Are there productivity spillovers from foreign direct investment in China?," Working Paper Series 2006-13, Federal Reserve Bank of San Francisco.

Halpern, L. and Muraközy, B. (2005) "Does Distance Matter in Spillover?", CEPR Discussion Paper No. 4857.

Havranek, Tomas Jiri and Irsova, Zuzana. (2008). "Meta-Analysis of Intra-Industry FDI Spillovers: Updated Evidence", IES Working Paper No. 8/2008. Available at SSRN: http://ssrn.com/abstract=1140707

Heckman, J. (1979). "Sample selection bias as a specification error", Econometrica, 47, pp. 153-161.

Hellman, J.S., Jones, G. and Kaufmann, D. (2002) "Far From Home: Do Foreign Investors Import Higher Standards of Governance in Transition Economies?," Development and Comp Systems 0308006, Econ WPA.

Javorcik, B. (2004) "Does Foreign Direct Investment Increase the Productivity of Domestic Firms? In Search of Spillovers through Backward Linkages," American Economic Review, American Economic Association, vol. 94(3), pages 605-627.

Javorcik, B. and Spatareanu, M. (2008) "To share or not to share: does local participation matter for spillovers from foreign direct investment?," Journal of Development Economics, 85(1-2), 194-217.

Javorcik, B. and Spatareanu, M. (2005) "Disentangling FDI Spillover Effects: What do Firm Perception Tell Us?”, in T. H. Moran, E. Graham and M. Blomstrom (eds) Does Foreign Direct Investment Promote Development?, Washington: Institute for International Economics.

Kekic, L. (2008) "Eastern Europe in 2009: The Outlook for Foreign Direct Investment", Economist Intelligence Unit, London, December 2008. PPT slides. 
Kinoshita, Y. (2000) "R\&D and technology spillovers via FDI: Innovation and absorptive capacity," CERGE-EI Working Papers Series No.163, The Center for Economic Research and Graduate Education - Economic Institute, Prague.

Kočenda E., Menezes A., Uzagalieva A. (2009), “Technological Imitation and Innovation in New European Union Markets", mimeo.

Konings, J. 1997. Firm Growth and Ownership in Transition Economies. Economics Letters, 55(3): 413-418.

Konings, J. (2001) "The Effects of Foreign Direct Investment on Domestic Firms: Evidence from Firm Level Panel Data in Emerging Economies”. Economics of Transition, Vol. 9, pp. 619-633.

Kolasa, M. (2007) "How does FDI inflow affect productivity of domestic firms? The role of horizontal and vertical spillovers, absorptive capacity and competition", National Bank of Poland Working Paper No. 42, Warsaw, March 2007.

Kosová, R. (2009). "Do Foreign Firms Crowd out Domestic Firms? Evidence from the Czech Republic", Working Paper 006, School of Business, The George Washington University. Forthcoming in Review of Economics and Statistics.

Lefilleur, J., Maurel, M. (2009), "Inter- and Intra-Industry Linkages as a Determinant of FDI in Central and Eastern Europe”, Economic Systems, forthcoming.

Levinsohn, J. and Petrin, A. (2003) "Estimating Production Functions Using Inputs to Control for Unobservables" Review of Economic Studies 70(2), 317-342.

Lutz, S., Talavera, O., and Park, S. (2008) "Effects of foreign presence in a transition economy: regional and industry-wide investments and firm-level Exports in Ukrainian Manufacturing”. Emerging Markets Finance \& Trade, Vol. 44, No. 5, pp. 82-98.

Meyer, K. E., Sinani, E. (2009) "Where and When Does Foreign Direct Investment Generate Positive Spillovers? A Meta Analysis". Erreur ! Référence de lien hypertexte non valide.Journal of International Business Studies, 40(7), 1075-1094.

Mayer-Foulkes, D., Nunnenkamp, P. (2009). Do Multinational Enterprises Contribute to Convergence or Divergence? A Disaggregated Analysis of US FDI. Review of Development Economics, 13 (2), 304-318.

Moulton, Brent R, 1990. "An Illustration of a Pitfall in Estimating the Effects of Aggregate Variables on Micro Unit," The Review of Economics and Statistics, 72(2), 334-38. 
Olley, S., and A. Pakes. 1996. The Dynamics of Productivity in the Telecommunications Equipment Industry. Econometrica 64, 1263-98.

Rose, A.K., T.D. Stanley, 2005, “A Meta-Analysis of the Effect of Common Currencies on International Trade", Journal of Economic Survey, 19, 3 (07): 347-365.

Sabirianova, K., Svejnar, J., Terrell, K. (2005) "Distance to the efficiency frontier and foreign direct investment spillovers". Journal of the European Economic Association April-May 2005, 3(2-3):576-586

Schoors, K., Van Der Tol, B. (2002) "Foreign direct investment spillovers within and between sectors: Evidence from Hungarian data." Working Papers of Faculty of Economics and Business Administration, Ghent University, Belgium 02/157, Ghent University, Faculty of Economics and Business Administration.

Schoors, K. and Merlevede, B. (2007) "FDI and the consequences towards more complete capture of spillover effects”. William Davidson Institute Working Paper No. 886.

Sinani, E. and Meyer, K. (2004) "Spillovers of technology transfer from FDI: the case of Estonia," Journal of Comparative Economics, 32(3), 445-466.

Sgard, J. (2001) "Direct Foreign Investments And Productivity Growth In Hungarian Firms, 1992-1999," William Davidson Institute Working Papers Series 425, William Davidson Institute at the University of Michigan Stephen M. Ross Business School.

Smeets, R. (2008) "Collecting the pieces of the FDI knowledge spillovers puzzle", International Bank for Reconstruction and Development, the World Bank, Research Observer,

Stančík, J. (2007) "Horizontal and vertical FDI spillovers: recent evidence from the Czech Republic", CERGE-EI Working Paper Series \#340, ISSN 1211-3298.

Stančík, J. (2009) "FDI Spillovers in the Czech Republic: Takeovers vs. Greenfields", European Economy, Economic Papers \#369, March 2009.

Stiglitz, Joseph J., (2000) "Capital Market Liberalization, Economic Growth, and Instability", World Development, 28(6), 1075-1086.

Tytell, I. and Yudaeva, K. (2006) "The role of FDI in Eastern Europe and New Independent States: new channels for the spillover effect". Center for Economic and Financial Research (CEFIR) Working Paper w0060.

Vahter, P. (2004) "The effect of foreign direct investment on labor productivity: evidence from Estonia and Slovenia”, ISSN 1406-5967, Tartu University Press, Order No. 527. 
Vahter, P. (2005) "Which Firms Benefit More From Inward Foreign Direct Investment?", Working Papers of Eesti Pank No 11.

Vahter, P. and Masso, J. (2005) "Home versus host country effects of FDI: searching for new evidence of productivity spillovers".

Wooster, R. and Diebel, D. (2006) "Productivity spillovers from Foreign Direct Investment in developing countries: a meta-regression analysis", Working paper series, Available at SSRN: http://ssrn.com/abstract=898400.

World Bank (2006), From Disintegration to Reintegration : Eastern Europe and the Former Soviet Union in International Trade, Washington, DC, USA.

Yudaeva, K., Kozlov, K., Melentieva, N., Ponomareva, N. (2003) "Does foreign ownership matter?," The Economics of Transition, The European Bank for Reconstruction and Development, vol. 11(3), pages 383-409, 09.

Zajc, K. (2006) "The role of Foreign Direct Investment in the firm selection process in a host country: evidence from Slovenia”. William Davidson Institute Working Paper No. 841.

Zukowska-Gagelmann, K. (2002) "Productivity Spillovers from Foreign Direct Investment in Poland”. Economic Systems, 24 (3): 223-56. 
Figure 1: Global inward FDI flows

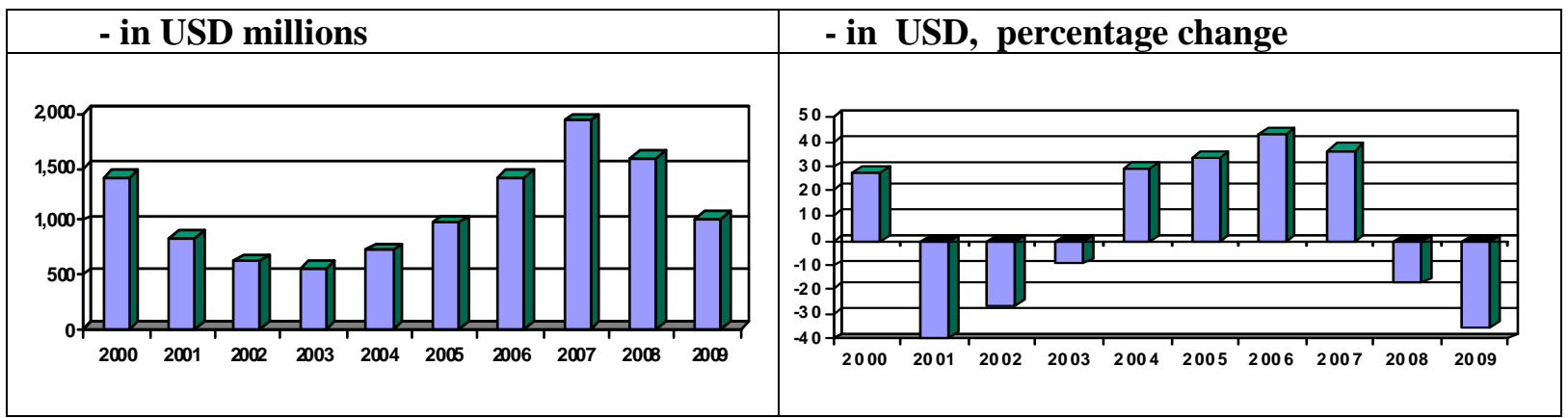

Source: Economist Intelligence Unit, December 2008

Figure 2: FDI inflows into Eastern Europe

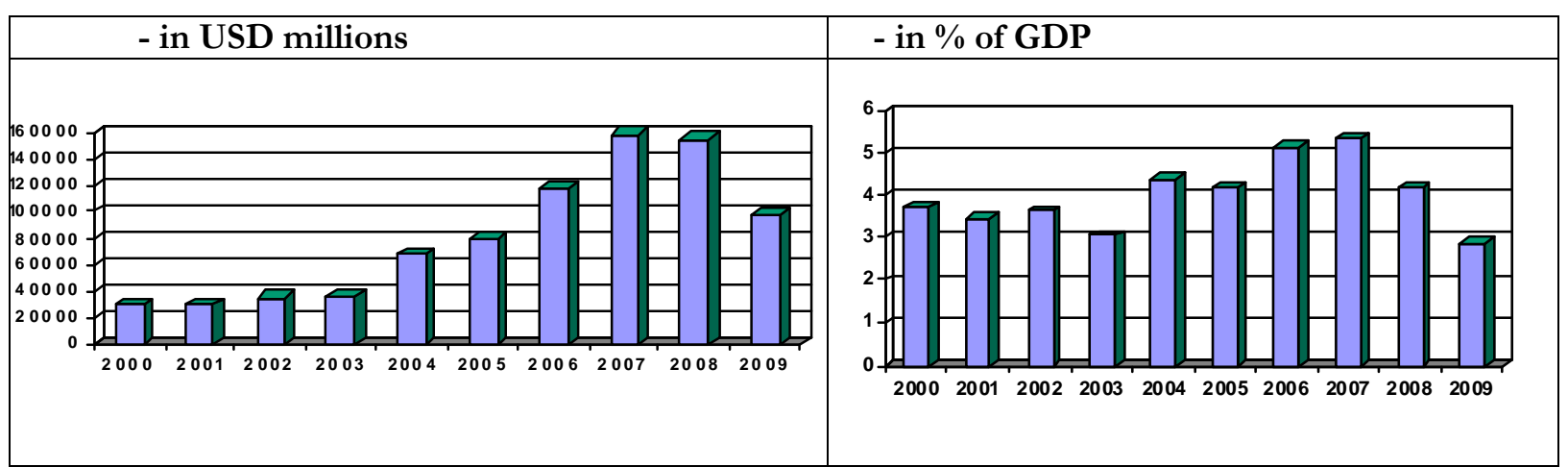

Source: Economist Intelligence Unit, December 2008 
Table 1: FDI by Region

\begin{tabular}{|c|c|c|c|c|c|c|}
\hline \multicolumn{7}{|c|}{ Foreign direct investment, net (BoP, current US\$) } \\
\hline & $\begin{array}{l}\text { East Asia } \\
\& \text { Pacific }\end{array}$ & $\begin{array}{c}\text { Europe \& } \\
\text { Central Asia }\end{array}$ & $\begin{array}{c}\text { Latin America \& } \\
\text { Caribbean }\end{array}$ & $\begin{array}{c}\text { Middle East \& } \\
\text { North Africa } \\
\end{array}$ & $\begin{array}{c}\text { South } \\
\text { Asia } \\
\end{array}$ & $\begin{array}{c}\text { Sub-Saharan } \\
\text { Africa } \\
\end{array}$ \\
\hline 1995 & & 0.00 & 26.11 & 0.87 & 2.81 & 1.52 \\
\hline 1996 & & 10.34 & 40.61 & 1.18 & 3.26 & 2.85 \\
\hline 1997 & & 13.66 & 58.01 & 2.23 & 4.81 & 5.48 \\
\hline 1998 & & 15.94 & 65.06 & 1.87 & 3.45 & 4.12 \\
\hline 1999 & & 14.73 & 80.74 & 2.02 & 2.97 & 6.78 \\
\hline 2000 & & 14.78 & 70.70 & 3.32 & 3.84 & 5.95 \\
\hline 2001 & & 16.41 & 67.42 & 3.43 & 4.69 & 16.60 \\
\hline 2002 & & 12.50 & 50.08 & 3.47 & 4.98 & 9.87 \\
\hline 2003 & & 15.46 & 36.67 & 5.89 & 3.45 & 10.47 \\
\hline 2004 & 62.40 & 38.09 & 48.57 & 5.05 & 5.34 & 7.76 \\
\hline 2005 & 86.23 & 40.26 & 53.13 & 12.71 & 7.40 & 13.16 \\
\hline 2006 & & 73.27 & 28.89 & 23.80 & 13.10 & 4.62 \\
\hline 2007 & & 96.43 & 84.44 & & & \\
\hline 2008 & & 101.61 & & & & \\
\hline \multicolumn{7}{|c|}{ Foreign direct investment, net inflows (BoP, current US\$) } \\
\hline 1995 & 50.80 & 9.44 & 30.18 & 0.82 & 2.93 & 4.55 \\
\hline 1996 & 58.64 & 11.55 & 43.81 & 1.26 & 3.51 & 4.07 \\
\hline 1997 & 62.22 & 18.14 & 65.70 & 3.58 & 4.90 & 8.59 \\
\hline 1998 & 57.82 & 18.29 & 73.35 & 3.55 & 3.55 & 6.86 \\
\hline 1999 & 50.40 & 18.00 & 87.85 & 2.61 & 3.08 & 9.46 \\
\hline 2000 & 45.17 & 19.07 & 79.34 & 4.88 & 4.36 & 6.80 \\
\hline 2001 & 48.92 & 19.75 & 72.03 & 4.05 & 6.14 & 14.20 \\
\hline 2002 & 59.40 & 18.02 & 52.96 & 4.97 & 6.70 & 10.21 \\
\hline 2003 & 56.77 & 28.61 & 42.20 & 7.86 & 5.38 & 12.98 \\
\hline 2004 & 70.35 & 55.12 & 64.89 & 7.49 & 7.59 & 10.68 \\
\hline 2005 & 104.36 & 61.59 & 70.85 & 16.12 & 9.98 & 16.98 \\
\hline 2006 & 105.15 & 113.35 & 71.48 & 28.07 & 23.16 & 18.47 \\
\hline 2007 & 175.34 & 151.52 & 107.27 & 28.91 & 29.93 & 28.73 \\
\hline
\end{tabular}

Source : World Bank Development Indicators 
Table 2: Economic Performance and FDI in Transition Countries (CEE, Balkans, CIS)

\begin{tabular}{|c|c|c|c|c|c|c|c|c|c|}
\hline & \multicolumn{3}{|c|}{ Real GDP growth, \% } & \multicolumn{3}{|c|}{ Inward FDI stocks, end-2007 } & \multicolumn{3}{|c|}{ Inward flows (USD bln) } \\
\hline & 2007 & 2008 & 2009 & USD bln & $\%$ of GDP & US\$ p.c. & 2007 & 2008 & 2009 \\
\hline Transition average & 7.6 & 5.8 & 2.2 & 1,046 & 35.4 & 2,590 & 158.5 & 155.4 & 98.1 \\
\hline Balkans & 6.2 & 6.6 & 2.2 & 141.0 & 41.8 & 2,660 & 31.0 & 29.1 & $\mathbf{1 7 . 7}$ \\
\hline Albania & 6.0 & 6.0 & 4.0 & 2.5 & 22.3 & 790 & 0.5 & 0.5 & 0.35 \\
\hline Bosnia, Herzegovina & 5.5 & 5.3 & 3.0 & 5.3 & 37.0 & 1,350 & 2.1 & 1.0 & 0.6 \\
\hline Bulgaria & 6.2 & 6.3 & 1.9 & 30.8 & 77.8 & 4,010 & 9.0 & 6.7 & 4.0 \\
\hline Croatia & 5.7 & 3.1 & 1.7 & 20.9 & 40.5 & 4,640 & 4.9 & 3.7 & 2.2 \\
\hline Macedonia & 5.1 & 5.3 & 3.0 & 3.1 & 44.0 & 1,510 & 0.3 & 0.6 & 0.3 \\
\hline Montenegro & 7.0 & 7.0 & 3.5 & 2.5 & 41.7 & 3,980 & 1.4 & 1.3 & 0.8 \\
\hline Romania & 6.0 & 8.2 & 2.6 & 60.9 & 36.2 & 2,820 & 9.4 & 12.0 & 7.5 \\
\hline Serbia & 7.5 & 6.0 & 1.0 & 15 & 8.1 & 2.020 & 3.4 & 3.3 & 2.0 \\
\hline Central Europe & 6.1 & 4.4 & 1.8 & 429.3 & 49.9 & 6,520 & 43.1 & 35.6 & 23.3 \\
\hline Czech Rep & 6.6 & 4.2 & 2.3 & 101.1 & 57.8 & 9,870 & 9.3 & 6.5 & 3.5 \\
\hline Hungary & 1.3 & 1.2 & -1.5 & 97.4 & 70.4 & 9,730 & 6.1 & 4.4 & 3.2 \\
\hline Poland. & 6.7 & 5.0 & 2.4 & 176.1 & 41.5 & 4,610 & 23.0 & 21.0 & 15.0 \\
\hline Slovakia & 10.4 & 6.8 & 3.0 & 40.7 & 54.2 & 7,480 & 3.3 & 2.4 & 1.2 \\
\hline Slovenia & 6.8 & 4.2 & 2.0 & 14.0 & 29.8 & 6,980 & 1.5 & 1.3 & 0.4 \\
\hline EU members & 6.3 & 4.8 & 2.3 & 563.4 & 48.8 & 5,530 & 68.3 & 59.5 & 37.4 \\
\hline Baltic countries & 8.7 & 1.0 & -2.6 & 42.4 & 48.7 & 5,990 & 6.8 & 5.2 & 2.6 \\
\hline Estonia & 6.3 & -2.0 & -2.5 & 16.7 & 79.8 & 12,380 & 2.7 & 2.4 & 1.3 \\
\hline Latvia & 10.3 & 5.9 & -7.0 & 10.6 & 39.1 & 4,610 & 2.2 & 1.5 & 0.5 \\
\hline Lithuania & 8.8 & 4.0 & 0.2 & 15.1 & 38.7 & 4,400 & 1.9 & 1.3 & 0.8 \\
\hline$\overline{\text { CIS }}$ & 8.5 & 6.5 & 2.5 & 433.6 & 25.9 & 1,560 & 77.7 & 85.5 & 54.5 \\
\hline Armenia & 13.7 & 9.0 & 4.5 & 2.5 & 27.3 & 830 & 0.7 & 0.5 & 0.4 \\
\hline Azerbaijan & 25.0 & 13.1 & 6.9 & 6.6 & 22.4 & 780 & -4.7 & -0.5 & 0.5 \\
\hline Belarus & 8.1 & 10.0 & 2.5 & 4.5 & 10.1 & 460 & 1.8 & 1.6 & 1.0 \\
\hline Georgia & 12.4 & 5.0 & 4.5 & 5.4 & 53.0 & 1,210 & 1.7 & 1.2 & 0.6 \\
\hline Kazakhstan & 8.5 & 3.5 & 3.0 & 43.6 & 41.9 & 2,860 & 10.3 & 6.5 & 4.0 \\
\hline Kyrgyzstan & 8.2 & 6.0 & 3.5 & 0.9 & 23.9 & 170 & 0.2 & 0.2 & 0.2 \\
\hline Moldova & 3.0 & 5.8 & 3.0 & 1.9 & 42.3 & 440 & 0.5 & 0.6 & 0.2 \\
\hline Russia & 8.1 & 6.7 & 3.0 & 324.1 & 25.1 & 2,260 & 55.1 & 60.0 & 40.0 \\
\hline Tajikistan & 7.8 & 5.8 & 2.5 & 1.1 & 28.2 & 150 & 0.4 & 0.5 & 0.3 \\
\hline Turkmenistan & 6.0 & 5.0 & 4.0 & 3.0 & 32.3 & 600 & 1.2 & 1.1 & 0.8 \\
\hline Ukraine & 7.7 & 4.5 & -3.0 & 38.1 & 27.0 & 810 & 9.9 & 13.0 & 6.0 \\
\hline Uzbekistan & 9.5 & 8.6 & 4.5 & 2.1 & 9.5 & 80 & 0.7 & 0.9 & 0.6 \\
\hline
\end{tabular}

Source: Economist Intelligence Unit, December 2008 
Table 3: Firm-level effects of FDIs - both direct and spillover

\begin{tabular}{|c|c|c|c|}
\hline Reference & $\begin{array}{l}\text { Country, period, } \\
\text { (N observations) }\end{array}$ & Measure of FDI & $\begin{array}{l}\text { Estimation } \\
\text { technique }\end{array}$ \\
\hline Bosco (2001) & $\begin{array}{l}\text { Hungary, 1993-1997, (N=587, } \\
1053)\end{array}$ & $\begin{array}{l}\text { Percentage of foreign } \\
\text { participation in the capital of a } \\
\text { firm. }\end{array}$ & $\begin{array}{l}\text { FE, First } \\
\text { differences }\end{array}$ \\
\hline $\begin{array}{l}\text { Damijan, Majcen, } \\
\text { Rojec, Knell (2003a) }\end{array}$ & $\begin{array}{l}\text { BG, CZ, EST, HU, PL, RO, SK, } \\
\text { SI, 1994-1998, (N=134-2199) }\end{array}$ & $\begin{array}{l}\text { Presence of foreign owner } \\
\text { (no/minor/major) }\end{array}$ & Heckman \& FE \\
\hline $\begin{array}{l}\text { Damijan, Majcen, } \\
\text { Rojec, Knell (2003b) }\end{array}$ & $\begin{array}{l}\text { BG, CZ, EST, HU, LT, LV, PL, } \\
\text { RO, SK, SLO, 1995-1999, } \\
(\mathrm{N}=398-5075)\end{array}$ & $\begin{array}{l}\text { FDI dummy if foreign capital } \\
>10 \% \text {, Majority foreign } \\
\text { ownership if foreign capital } \\
>50 \%\end{array}$ & $\begin{array}{l}\text { Heckman \& sys- } \\
\text { GMM }\end{array}$ \\
\hline $\begin{array}{l}\text { Djankov and } \\
\text { Hoekman (1999) }\end{array}$ & $\begin{array}{l}\mathrm{CZ}, 1992-1996, \quad(\mathrm{~N}=513,340, \\
431)\end{array}$ & $\begin{array}{l}\text { FDI dummy, Joint Venture } \\
\text { dummy }\end{array}$ & OLS, RE \\
\hline $\begin{array}{l}\text { Evenett and Voicu } \\
(2001)\end{array}$ & $\mathrm{CZ}, 1995-1998,(\mathrm{~N}=3188)$ & FDI dummy & Heckman \\
\hline $\begin{array}{l}\text { Frydman, Gray, } \\
\text { Hessel and } \\
\text { Rapaczynski (1999) }\end{array}$ & $\begin{array}{l}\mathrm{CZ}, \quad \mathrm{HU}, \quad \mathrm{PL}, \quad 1990-1993, \\
(\mathrm{~N}=513)\end{array}$ & $\begin{array}{l}\text { Dummy equal to } 1 \text { if the largest } \\
\text { shareholder is a foreign owner }\end{array}$ & $\mathrm{FE}$ \\
\hline $\begin{array}{l}\text { Gorodnichenko, } \\
\text { Svejnar, Terrel } \\
(\mathbf{2 0 0 6 )}\end{array}$ & $\begin{array}{l}\text { AL, BG, HR, CZ, EE, HU, KZ, } \\
\text { LV, LT, PL, RO, RU, SK, SI, } \\
\text { UA }\end{array}$ & $\begin{array}{l}\text { Share of foreign ownership in } \\
\text { industry }\end{array}$ & First difference \\
\hline $\begin{array}{l}\text { Hanousek, Kocenda, } \\
\text { Svejnar (2007) }\end{array}$ & CZ, 1996-1999, (N=2168-2949) & $\begin{array}{l}\text { Three types of foreign } \\
\text { ownership: Majority Foreign, } \\
\text { Blocking Minority Foreign, } \\
\text { Legal Minority Foreign }\end{array}$ & Diff. OLS, IV \\
\hline $\begin{array}{l}\text { Hellman, Jones and } \\
\text { Kaufmann (2002) }\end{array}$ & $\begin{array}{l}\text { AL, AM, AZ, BY, BG, HR, } \\
\text { CZ, EE, GE, HU, KZ, KG, LV, } \\
\text { LT, MD, PL, RO, RU, SK, SI, } \\
\text { UA, UZ, 1989-2000, (N=2685) }\end{array}$ & FDI dummy & OLS \\
\hline Javorcik (2004) & LT, 1996-2000, $(\mathrm{N}=681-11630)$ & $\begin{array}{l}\text { Foreign share, Forward, } \\
\text { Backward, Horizontal }\end{array}$ & $\begin{array}{l}\text { OLS, First } \\
\text { Difference, } \\
\text { Olley\&Pakes }\end{array}$ \\
\hline $\begin{array}{l}\text { Javorcik and } \\
\text { Spatareanu (2005) }\end{array}$ & $\begin{array}{l}\mathrm{CZ}, \mathrm{RO}, 1998-2000,(\mathrm{~N}=71517 \\
7400)\end{array}$ & Vertical, Horizontal & $\begin{array}{l}\text { First Difference, } \\
\text { Olley\&Pakes }\end{array}$ \\
\hline Kinoshita (2000) & $\mathrm{CZ}, 1995-1998,(\mathrm{~N}=704)$ & $\begin{array}{l}\text { Foreign ownership dummy, } \\
\text { employment share of foreign } \\
\text { firms to that of all firms in the } \\
\text { industry }\end{array}$ & OLS \\
\hline
\end{tabular}

(continue on the next page) 
Table 3 (continue): Firm-level effects of FDIs - both direct and spillover

\begin{tabular}{|c|c|c|c|}
\hline Reference & $\begin{array}{l}\text { Country, period, } \\
\text { (N observations) }\end{array}$ & Measure of FDI & $\begin{array}{l}\text { Estimation } \\
\text { technique }\end{array}$ \\
\hline Konigs (2000) & $\begin{array}{l}\mathrm{BG}, \mathrm{PL}, \mathrm{RO}, 1993-1997 \\
(1994-1997 \text { in case of RO), } \\
(\mathrm{N}=6361,8580,2854)\end{array}$ & $\begin{array}{l}\text { Fraction of shares held by a foreign } \\
\text { investor, Share of output accounted for } \\
\text { by foreign firms in total output at the } 2 \text { - } \\
\text { digit NACE sector level }\end{array}$ & $\begin{array}{l}\text { First } \\
\text { differencing, } \\
\text { GMM IV }\end{array}$ \\
\hline $\begin{array}{l}\text { Sabirianova, } \\
\text { Svejnar, Terrel } \\
(\mathbf{2 0 0 5 )}\end{array}$ & $\begin{array}{l}\mathrm{CZ}, \quad \mathrm{RU}, \quad 1992-2000 \\
(\mathrm{~N}=18434,136769)\end{array}$ & Foreign ownership & $\begin{array}{l}\text { OLS,RE, FE, } \\
2 \text { SLS-RE }\end{array}$ \\
\hline $\begin{array}{l}\text { Schoors and Van } \\
\text { der Tol (2002) }\end{array}$ & $\begin{array}{l}\mathrm{HU}, 1997-1998, \quad(\mathrm{~N}=819- \\
1021)\end{array}$ & Foreign participation $(10 \%, 50 \%, 95 \%)$ & OLS, IV \\
\hline Sgard (2001) & $\begin{array}{l}\mathrm{HU}, \\
(\mathrm{N}=33033)\end{array}$ & $\begin{array}{l}\text { Share of foreign equity in a firm, share } \\
\text { of foreign equity in a sector }\end{array}$ & $\begin{array}{l}\text { OLS, First to } \\
\text { fourth } \\
\text { differences }\end{array}$ \\
\hline $\begin{array}{l}\text { Sinani and Meyer } \\
(2004)\end{array}$ & $\begin{array}{l}\mathrm{EE}, \quad 1994-1999, \quad(\mathrm{~N}=455 \\
374,334)\end{array}$ & $\begin{array}{l}\text { Share of foreign firms' in industry } \\
\text { employment, sales, and equity as proxies } \\
\text { for spillovers }\end{array}$ & FE, GLS \\
\hline Vahter (2004) & $\begin{array}{l}\text { EE, SI, 1996-2001 for EE, } \\
1994-2000 \text { for SI, } \\
(\mathrm{N}=6780)\end{array}$ & $\begin{array}{l}\text { FDI dummy (majority FDI dummy in } \\
\text { case of Estonia), share of FDI in a sector }\end{array}$ & $\begin{array}{l}\text { RE, FE, } \\
\text { Heckman }\end{array}$ \\
\hline Vahter (2005) & $\mathrm{EE}, 1996-2001,(\mathrm{~N}=1915)$ & $\begin{array}{l}\text { FDI dummy (foreign share equal to at } \\
\text { least } 50 \% \text { ) }\end{array}$ & $\mathrm{FE}$, \\
\hline $\begin{array}{l}\text { Vahter and } \\
\text { Musso (2005) }\end{array}$ & $\begin{array}{l}\mathrm{EE}, 1995-2002,(\mathrm{~N}=15226, \\
56143)\end{array}$ & $\begin{array}{l}\text { FDI dummy (foreign share equal to at } \\
\text { least } 50 \% \text { ) }\end{array}$ & OLS, FE, RE \\
\hline $\begin{array}{l}\text { Yudaeva et al } \\
(2003)\end{array}$ & $\begin{array}{l}\text { RU, } \\
(\mathrm{N}=11029)\end{array}$ & $\begin{array}{l}\text { FDI dummy (foreign share equal to at } \\
\text { least } 10 \% \text { or as defined elsewhere) }\end{array}$ & OLS, FE, IV \\
\hline
\end{tabular}

Notes: Estimation techniques abbreviations denote Ordinary Least Squares (OLS), Instrumental Variable (IV), Fixed Effects (FE), Random Effects (RE). Country codes denote Bulgaria (BG), Czech Republic (CZ), Estonia (EE), Hungary (HU), Latvia (LV), Lithuania (LT), Poland (PL), Romania (RO), Slovak Republic (SK), Slovenia (SI), Turkey (TR), Austria (AT), Belgium (BE), Luxembourg (LU), Denmark (DK), Finland (FI), France (FR), Germany (DE), Greece (GR), Ireland (IE), Italy (IT), Netherlands (NL), Portugal (PT), Spain (ES), Sweden (SE), United Kingdom (UK), Norway (NO), Switzerland (CH), Albania (AL), Armenia (AM), Azerbaijan (AZ), Belarus (BY), Croatia (HR), Georgia (GE), Kazakhstan (KZ), Kyrgyzstan (KZ), Moldova (MD), Russia (RU), Ukraine (UA), Uzbekistan (UZ) 
Table 4: Are FDI direct effect significant?

A Meta Analysis with (and without) Country and Region Dummies

\begin{tabular}{|c|c|c|c|c|c|c|}
\hline & Coefficient & $\begin{array}{l}\text { Standard } \\
\text { error }\end{array}$ & Coefficient & $\begin{array}{l}\text { Standard } \\
\text { error }\end{array}$ & Coefficient & $\begin{array}{l}\text { Standard } \\
\text { error }\end{array}$ \\
\hline Average trend & $-1,453^{\mathrm{a}}$ & 0,517 & $-3,237^{a}$ & 0,338 & $-3,883^{\mathrm{a}}$ & 0,292 \\
\hline Published & $-1,946$ & 1,923 & $-9,154^{\mathrm{a}}$ & 0,986 & $-8,987^{\mathrm{a}}$ & 0,996 \\
\hline Working Paper & 0,044 & 1,750 & $-5,955^{\mathrm{a}}$ & 1,104 & $-5,401^{\mathrm{a}}$ & 1,083 \\
\hline Panel & $-5,092^{b}$ & 2,385 & $-4,445^{\mathrm{a}}$ & 1,308 & $-3,379^{\mathrm{a}}$ & 0,688 \\
\hline \multicolumn{7}{|c|}{ Performance measured by : } \\
\hline Output per worker & $12,263^{\mathrm{a}}$ & 0,848 & $11,031^{\mathrm{a}}$ & 0,669 & $10,360^{\mathrm{a}}$ & 0,617 \\
\hline Output growth & $-2,510$ & 1,604 & $-3,535^{b}$ & 1,411 & $-2,792^{b}$ & 1,434 \\
\hline \multicolumn{7}{|l|}{ Country dummies } \\
\hline EST & $4,703^{b}$ & 1,905 & & & & \\
\hline HUN & $5,460^{\mathrm{a}}$ & 1,552 & & & & \\
\hline LTU & $-4,241^{b}$ & 1,819 & & & & \\
\hline LVA & 1,634 & 2,082 & & & & \\
\hline POL & $-0,537$ & 1,843 & & & & \\
\hline ROM & 1,436 & 1,843 & & & & \\
\hline RUS & $-1,366$ & 2,270 & & & & \\
\hline SLO & $4,755^{\mathrm{b}}$ & 1,905 & & & & \\
\hline SVK & 2,227 & 1,905 & & & & \\
\hline UKR & (dropped) & & & & & \\
\hline CZE & $3,512^{\mathrm{b}}$ & 1,569 & & & & \\
\hline \multicolumn{7}{|l|}{ Region dummies } \\
\hline Visegrad5 & & & $3,130^{\mathrm{a}}$ & 1,070 & & \\
\hline Baltic countries & & & 0,126 & 1,244 & & \\
\hline CIS & & & (dropped) & & & \\
\hline constant & $7,765^{b}$ & 3,044 & $18,983^{\mathrm{a}}$ & 1,677 & $21,365^{\mathrm{a}}$ & 1,580 \\
\hline R squared & $\overline{0.753}$ & & $\overline{0.722}$ & & 0.707 & \\
\hline Number of observations & 302 & & 302 & & 302 & \\
\hline
\end{tabular}

Note: Country dummies in specification are to capture specific effect of country or regional group of countries. The abbreviations are as follows: Estonia (EST), Hungary (HUN), Lithuania (LTU), Latvia (LVA), Poland (POL), Romania (ROM), Russia (RUS), Slovenia (SLO), Slovakia (SVK), Ukraine (UKR), Czech Republic (CZE). There are also following region dummies. Balkan covers Albania, Bosnia, Herzegovina, Bulgaria, Croatia, Macedonia, Montenegro, Romania, Serbia. Visegrad5 covers Czech Republic, Hungary, Poland, Slovakia, Slovenia. Baltic Countries covers Estonia, Lithuania, Latvia. CIS covers Commonwealth of Independent States as listed in Table 2.

Statistical significance of coefficients is denoted as follows: a (1\%), b (5\%), and c (10\%). 
Table 5: Do FDI Produce spillover effects?

A Meta Analysis with (and without) Country and Region Dummies

\begin{tabular}{|c|c|c|c|c|c|c|}
\hline & Coefficient & $\begin{array}{l}\text { Standard } \\
\text { error }\end{array}$ & Coefficient & $\begin{array}{l}\text { Standar } \\
\text { d error }\end{array}$ & Coefficient & $\begin{array}{l}\text { Standard } \\
\text { error }\end{array}$ \\
\hline Average trend & $-0,467^{a}$ & 0,181 & $-0,329^{a}$ & 0,107 & $-0,231^{b}$ & 0,094 \\
\hline Published & $-1,549^{\mathrm{c}}$ & 0,934 & $-1,810^{b}$ & 0,764 & $-1,160^{\mathrm{c}}$ & 0,685 \\
\hline Working Paper & $-0,398$ & 0,885 & $-0,760$ & 0,743 & $-0,631$ & 0,648 \\
\hline Panel & $-4,606^{\mathrm{a}}$ & 1,006 & $-4,249^{\mathrm{a}}$ & 0,836 & $-4,326^{\mathrm{a}}$ & 0,811 \\
\hline \multicolumn{7}{|l|}{ Spillover measured by: } \\
\hline Employment share & $1,456^{\mathrm{a}}$ & 0,506 & $1,486^{\mathrm{a}}$ & 0,502 & $1,418^{\mathrm{a}}$ & 0,502 \\
\hline Value added share & $-3,265^{\mathrm{a}}$ & 0,520 & $-3,147^{\mathrm{a}}$ & 0,469 & $-3,075^{\mathrm{a}}$ & 0,454 \\
\hline \multicolumn{7}{|c|}{ Performance measured by : } \\
\hline Output per worker & $2,744^{\mathrm{a}}$ & 0,506 & $2,177^{\mathrm{a}}$ & 0,385 & $1,806^{\mathrm{a}}$ & 0,351 \\
\hline Output growth & $-1,504$ & 1,274 & $-1,694$ & 1,103 & $-1,425$ & 1,095 \\
\hline \multicolumn{7}{|l|}{ Country dummies } \\
\hline EST & $-0,759$ & 0,800 & & & & \\
\hline HUN & $-0,920$ & 0,965 & & & & \\
\hline LTU & $-1,500^{c}$ & 0,859 & & & & \\
\hline LVA & $-1,702$ & 1,337 & & & & \\
\hline POL & $-1,311$ & 1,082 & & & & \\
\hline $\mathrm{ROM}$ & $-1,878^{b}$ & 0,889 & & & & \\
\hline RUS & $-1,563$ & 1,021 & & & & \\
\hline SLO & $-1,033$ & 1,205 & & & & \\
\hline SVK & $-0,980$ & 1,205 & & & & \\
\hline UKR & 1,427 & 0,915 & & & & \\
\hline CZE & $-0,973$ & 0,953 & & & & \\
\hline \multicolumn{7}{|l|}{ Region dummies } \\
\hline Balkan & & & $-1,069^{\mathrm{c}}$ & 0,643 & & \\
\hline Visegrad5 & & & $-0,338$ & 0,588 & & \\
\hline Baltic countries & & & $-0,752^{\mathrm{c}}$ & 0,464 & & \\
\hline CIS & & & $1,577^{\mathrm{b}}$ & 0,799 & & \\
\hline constant & $8,217^{\mathrm{a}}$ & 2,134 & $7,420^{\mathrm{a}}$ & 1,398 & $6,545^{\mathrm{a}}$ & 1,239 \\
\hline R squared & 0,097 & & 0,099 & & 0,089 & \\
\hline Number of observations & 868 & & 868 & & 868 & \\
\hline
\end{tabular}

Note: Country dummies in specification are to capture specific effect of country or regional group of countries. The abbreviations are as follows: Estonia (EST), Hungary (HUN), Lithuania (LTU), Latvia (LVA), Poland (POL), Romania (ROM), Russia (RUS), Slovenia (SLO), Slovakia (SVK), Ukraine (UKR), Czech Republic (CZE). There are also following region dummies. Balkan covers Albania, Bosnia, Herzegovina, Bulgaria, Croatia, Macedonia, Montenegro, Romania, Serbia. Visegrad5 covers Czech Republic, Hungary, Poland, Slovakia, Slovenia. Baltic Countries covers Estonia, Lithuania, Latvia. CIS covers Commonwealth of Independent States as listed in Table 2.

Statistical significance of coefficients is denoted as follows: a (1\%), b (5\%), and c (10\%). 
Table 6 : Vertical Spillover Effect versus Horizontal Effect and Absorbing Capacity

A Meta Analysis with (and without) Country Dummies

\begin{tabular}{|c|c|c|c|c|c|c|c|c|c|c|c|c|}
\hline & \multicolumn{2}{|l|}{ (1) } & \multicolumn{2}{|l|}{$(2)$} & \multicolumn{2}{|l|}{ (3) } & \multicolumn{2}{|l|}{ (1') } & \multicolumn{2}{|l|}{$\left(\mathbf{2}^{\prime}\right)$} & \multicolumn{2}{|l|}{ (3') } \\
\hline & Coefficient & $\begin{array}{l}\text { Standard } \\
\text { error }\end{array}$ & Coefficient & $\begin{array}{l}\text { Standard } \\
\text { error }\end{array}$ & Coefficient & $\begin{array}{l}\text { Standard } \\
\text { error }\end{array}$ & Coefficient & $\begin{array}{l}\text { Standard } \\
\text { error }\end{array}$ & Coefficient & $\begin{array}{l}\text { Standard } \\
\text { error }\end{array}$ & Coefficient & $\begin{array}{l}\text { Standard } \\
\text { error }\end{array}$ \\
\hline Average trend & $-0,519^{\mathrm{a}}$ & $\overline{0,182}$ & $-0,440^{\mathrm{b}}$ & $\overline{0,181}$ & $-0,538^{\mathrm{a}}$ & 0,183 & $-0,297^{\mathrm{a}}$ & $\overline{0,096}$ & $-0,236^{b}$ & 0,094 & $-0,281^{\mathrm{c}}$ & 0,096 \\
\hline Published & $-1,155$ & 0,945 & $-1,231$ & 0,942 & $-1,469$ & 0,939 & $-1,183^{\mathrm{c}}$ & 0,686 & $-1,079$ & 0,689 & $-1,219^{\mathrm{c}}$ & 0,684 \\
\hline Working Paper & $-0,217$ & 0,890 & $-0,392$ & 0,889 & $-0,166$ & 0,889 & $-0,635$ & 0,648 & $-0,708$ & 0,653 & $-0,478$ & 0,646 \\
\hline Panel & $-5,087^{\mathrm{a}}$ & 1,013 & $-4,436^{\mathrm{a}}$ & 1,005 & $-5,233^{\mathrm{a}}$ & 1,019 & $-4,598^{\mathrm{a}}$ & 0,819 & $-4,297^{\mathrm{a}}$ & 0,811 & $-4,638^{\mathrm{a}}$ & 0,822 \\
\hline \multicolumn{13}{|c|}{ Spillover measured by share of: } \\
\hline Employment & $1,542^{\mathrm{a}}$ & 0,518 & $1,767^{\mathrm{a}}$ & 0,518 & $1,281^{\mathrm{b}}$ & 0,509 & $1,445^{\mathrm{a}}$ & 0,514 & $1,631^{\mathrm{a}}$ & 0,515 & $1,263^{\mathrm{b}}$ & 0,503 \\
\hline Value added & $-3,334^{a}$ & 0,523 & $-3,092^{\mathrm{a}}$ & 0,522 & $-3,484^{a}$ & 0,523 & $-3,118^{a}$ & 0,455 & $-2,976^{\mathrm{a}}$ & 0,458 & $-3,201^{a}$ & 0,453 \\
\hline \multicolumn{13}{|c|}{ Performance measured by : } \\
\hline $\begin{array}{l}\text { Output per } \\
\text { worker }\end{array}$ & $2,579^{\mathrm{a}}$ & 0,517 & $2,927^{\mathrm{a}}$ & 0,508 & $2,404^{\mathrm{a}}$ & 0,518 & $1,471^{\mathrm{a}}$ & 0,363 & $1,875^{\mathrm{a}}$ & 0,353 & $1,429^{\mathrm{a}}$ & 0,364 \\
\hline Output growth & $-1,042$ & 1,280 & $-1,072$ & 1,278 & $-1,585$ & 1,279 & $-1,268$ & 1,092 & $-1,239$ & 1,096 & $-1,531$ & 1,095 \\
\hline \multicolumn{13}{|c|}{ Country dummies } \\
\hline EST & $-0,797$ & 0,793 & $-0,621$ & 0,798 & $-0,934$ & 0,797 & & & & & & \\
\hline HUN & $-1,100$ & 0,966 & $-0,636$ & 0,966 & $-1,355$ & 0,968 & & & & & & \\
\hline LTU & $-1,995^{\mathrm{b}}$ & 0,859 & $-1,773^{\mathrm{b}}$ & 0,863 & $-1,681^{b}$ & 0,857 & & & & & & \\
\hline LVA & $-1,828$ & 1,322 & $-1,733$ & 1,332 & $-1,783$ & 1,330 & & & & & & \\
\hline POL & $-1,293$ & 1,070 & $-1,311$ & 1,078 & $-1,295$ & 1,077 & & & & & & \\
\hline ROM & $-1,853^{\mathrm{b}}$ & 0,882 & $-1,690^{\mathrm{b}}$ & 0,887 & $-2,044^{\mathrm{b}}$ & 0,886 & & & & & & \\
\hline RUS & $-1,869^{\mathrm{c}}$ & 1,010 & $-1,619$ & 1,017 & $-1,765^{\mathrm{c}}$ & 1,017 & & & & & & \\
\hline SLO & $-1,109$ & 1,192 & $-0,993$ & 1,200 & $-1,143$ & 1,200 & & & & & & \\
\hline SVK & $-1,057$ & 1,192 & $-0,941$ & 1,200 & $-1,091$ & 1,200 & & & & & & \\
\hline UKR & 1,026 & 0,919 & $1,626^{\mathrm{c}}$ & 0,914 & 0,892 & 0,923 & & & & & & \\
\hline CZE & $-1,206$ & 0,944 & $-0,987$ & 0,949 & $-1,153$ & 0,950 & & & & & & \\
\hline
\end{tabular}

(continue on the next page) 
Table 6. (Continue)

(2)

(2)

Coefficient Standard error

Coefficient Standard

(3)

\section{Spillover Interacted with :}

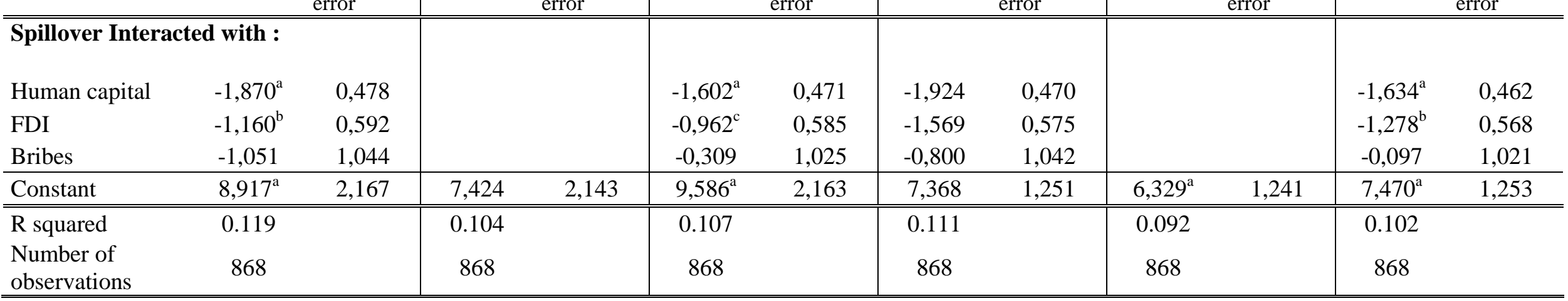

Note: Country dummies in specification are to capture specific effect of country or regional group of countries. The abbreviations are as follows: Estonia (EST), Hungary (HUN), Lithuania (LTU), Latvia (LVA), Poland (POL), Romania (ROM), Russia (RUS), Slovenia (SLO), Slovakia (SVK), Ukraine (UKR), Czech Republic (CZE). There are also following region dummies. Balkan covers Albania, Bosnia, Herzegovina, Bulgaria, Croatia, Macedonia, Montenegro, Romania, Serbia. Visegrad5 covers Czech

Republic, Hungary, Poland, Slovakia, Slovenia. Baltic Countries covers Estonia, Lithuania, Latvia. CIS covers Commonwealth of Independent States as listed in Table 2. Statistical significance of coefficients is denoted as follows: a (1\%), b (5\%), and c (10\%). 
Table 7. Vertical spillover effect versus horizontal effect and absorbing capacity. A meta analysis with region dummies

\begin{tabular}{|c|c|c|c|c|c|c|}
\hline \multicolumn{3}{|c|}{ (4) } & \multicolumn{2}{|l|}{ (5) } & \multicolumn{2}{|l|}{ (6) } \\
\hline & Coefficient & $\begin{array}{l}\text { Standard } \\
\text { error }\end{array}$ & Coefficient & $\begin{array}{l}\text { Standard } \\
\text { error }\end{array}$ & Coefficient & $\begin{array}{l}\text { Standard } \\
\text { error }\end{array}$ \\
\hline Average trend & $-0,382^{\mathrm{a}}$ & 0,107 & $-0,343^{\mathrm{a}}$ & 0,107 & $-0,361^{a}$ & 0,108 \\
\hline Published & $-1,679^{b}$ & 0,763 & $-1,804^{b}$ & 0,764 & $-1,659^{b}$ & 0,764 \\
\hline Working Paper & $-0,794$ & 0,747 & $-0,973$ & 0,749 & $-0,504$ & 0,745 \\
\hline Panel & $-4,557^{\mathrm{a}}$ & 0,845 & $-4,252^{a}$ & 0,835 & $-4,561^{\mathrm{a}}$ & 0,849 \\
\hline \multicolumn{7}{|c|}{ Spillover measured by share of: } \\
\hline Employment share & $1,570^{\mathrm{a}}$ & 0,517 & $1,778^{\mathrm{a}}$ & 0,516 & $1,320^{\mathrm{a}}$ & 0,506 \\
\hline Value added share & $-3,197^{\mathrm{a}}$ & 0,468 & $-3,052^{\mathrm{a}}$ & 0,470 & $-3,269^{a}$ & 0,469 \\
\hline \multicolumn{7}{|c|}{ Performance measured by : } \\
\hline Output per worker & $1,825^{\mathrm{a}}$ & 0,404 & $2,285^{\mathrm{a}}$ & 0,388 & $1,757^{\mathrm{a}}$ & 0,406 \\
\hline Output growth & $-1,459$ & 1,102 & $-1,488$ & 1,103 & $-1,735$ & 1,105 \\
\hline \multicolumn{7}{|l|}{ Region dummies } \\
\hline Balkan & $-0,838$ & 0,643 & $-0,907$ & 0,644 & $-1,045$ & 0,644 \\
\hline Visegrad5 & $-0,306$ & 0,585 & $-0,241$ & 0,587 & $-0,419$ & 0,587 \\
\hline Baltic countries & $-0,827^{\mathrm{b}}$ & 0,464 & $-0,795^{\mathrm{c}}$ & 0,465 & $-0,791^{\mathrm{c}}$ & 0,464 \\
\hline CIS & 1,290 & 0,805 & $1,807^{\mathrm{b}}$ & 0,801 & 1,110 & 0,807 \\
\hline Vertical Forward & $2,248^{\mathrm{a}}$ & 0,725 & $1,501^{\mathrm{b}}$ & 0,694 & & \\
\hline Vertical Backward & $0,651^{\mathrm{c}}$ & 0,354 & $0,668^{\mathrm{c}}$ & 0,356 & & \\
\hline \multicolumn{7}{|c|}{ Spillover Interacted with : } \\
\hline Human capital & $-1,767^{\mathrm{a}}$ & 0,474 & & & $-1,498^{\mathrm{a}}$ & 0,467 \\
\hline FDI & $-1,286^{\mathrm{b}}$ & 0,580 & & & $-1,011^{\mathrm{c}}$ & 0,573 \\
\hline Bribes & $-0,819$ & 1,040 & & & $-0,124$ & 1,020 \\
\hline Constant & $8,097^{\mathrm{a}}$ & 1,402 & 7,244 & 1,396 & $8,179^{\mathrm{a}}$ & 1,409 \\
\hline R squared & 0.118 & & 0.104 & & 0.108 & \\
\hline Number of observations & 868 & & 868 & & 868 & \\
\hline
\end{tabular}

Note: Region dummies are defined as follows. Balkan covers Albania, Bosnia, Herzegovina, Bulgaria, Croatia, Macedonia, Montenegro, Romania, Serbia. Visegrad5 covers Czech Republic, Hungary, Poland, Slovakia, Slovenia. Baltic Countries covers Estonia, Lithuania, Latvia. CIS covers Commonwealth of Independent States as listed in Table 2.

Statistical significance of coefficients is denoted as follows: a (1\%), b (5\%), and c (10\%). 